\title{
Tectonics
}

\author{
RESEARCH ARTICLE \\ 10.1029/2020TC006379 \\ Key Points: \\ - An early Eocene NE-directed \\ tectonic phase is responsible for the \\ Barrovian metamorphism observed \\ across the Miyar Thrust Zone \\ - Microstuctures and monazite \\ geochronology reveal that the Miyar \\ Thrust Zone acted in two successive \\ phases: an Eocene and an Oligocene \\ phase \\ - The Miyar Thrust Zone corresponds \\ to the frontal thrust of a nappe \\ sourced from the southwest \\ Supporting Information: \\ - Table S1 \\ - Table S2
}

Correspondence to:

M. Robyr,

martin.robyr@unil.ch

Citation:

Robyr, M., \& Lanari, P. (2020).

Kinematic, metamorphic, and age constraints on the Miyar Thrust Zone: Implications for the Eohimalayan history of the High Himalayan

Crystalline of NW India. Tectonics, 39, e2020TC006379. https://doi.org/

10.1029/2020TC006379

Received 12 JUN 2020

Accepted 31 OCT 2020

Accepted article online 9 NOV 2020

(C)2020. American Geophysical Union. All Rights Reserved.

\section{Kinematic, Metamorphic, and Age Constraints on the Miyar Thrust Zone: Implications for the Eohimalayan History of the High Himalayan Crystalline of NW India}

\author{
Martin Robyr ${ }^{1,2}$ and Pierre Lanari ${ }^{2}$ \\ ${ }^{1}$ Institute of Earth Sciences, University of Lausanne, Lausanne, Switzerland, ${ }^{2}$ Institute of Geological Sciences, University \\ of Bern, Bern, Switzerland
}

\begin{abstract}
NE-vergent folds and thrust faults are an enigmatic feature of the High Himalayan Crystalline in the NW Indian Himalaya, as these structures are in marked contrast to the SW-directed thrusts and fold vergences that predominate in the rest of the Himalaya since the continental collision between India and Asia. However, it is controversial whether these unusual NE-vergent structures reflect local heterogeneities in strain during the main SW-vergent deformation or whether they are associated with a postulated NE-directed early Eocene deformation phase. In this study, microstructural analysis and monazite geochronology across the SW-dipping Miyar Shear Zone (Miyar Valley, NW India) reveal that these NE-verging structures result from a NE-directed propagation of crustal deformation that was initiated before $40 \mathrm{Ma}$, likely slightly after continental collision at ca. $55 \mathrm{Ma}$. The new data presented in this study identify that the kinematic evolution of the High Himalayan Crystalline in NW India was initially controlled by an early Eocene NE-directed crustal thickening phase. Consequently, the SW-verging kinematic evolution widely accepted for the High Himalayan Crystalline in the central and eastern Himalayan sections should be reconsidered for the western part of the Indian Himalaya. In a broader sense, these results reveal that crustal shortening during the initial stage of continental subduction is not exclusively accommodated by foreland-directed folding and thrusting but may also be adapted by deformation involving opposite-directed vergence.
\end{abstract}

\section{Introduction}

SW-vergent folding and thrusting along major NE-dipping thrust zones and shear zones have been the predominant tectonic structures developed within the Indian continental crust to accommodate crustal shortening since the onset of continental collision between India and Asia 55 Myr ago (de Sigoyer et al., 2000; Garzanti et al., 1987; Patriat \& Achache, 1984; Rowley, 1996) (Figure 1). However, over the last decades, NE-directed tectonic structures have been described in the High Himalayan Crystalline (HHC) of Upper Lahul in the northwestern Indian Himalaya (Epard et al., 1995; Pognante et al., 1990; Robyr et al., 2002, 2006, 2014; Schlup et al., 2011; Steck, 2003; Steck, Spring, Vannay, Masson, Bucher, et al., 1993; Steck, Spring, Vannay, Masson, Stutz, et al., 1993; Steck et al., 1998, 1999; Vannay \& Steck, 1995; Wyss et al., 1999). These structures consist of NE-vergent folds and NE-directed thrust faults, in sharp contrast to the SW-directed folding and thrusting that characterize much of the Himalayan kinematic since the continental collision. Various interpretations have been proposed to explain these uncommon NE-verging structures. A first interpretation argued that the unusual vergence of these structures reflects local heterogeneities in strain during the main SW-directed folding phase (Frank et al., 1987; Singh, 2012). A second interpretation suggested that these structures rather reflect NE-directed tectonic movements associated with a late backfolding phase (Fuchs \& Linner, 1995). Next, Dèzes et al. (1999) proposed that the NE-verging thrust faults observed in Upper Lahul represent the folded equivalent of the NE-dipping extensional shear zone that developed at the top of the HHC during its early Miocene southward extrusion. More recently, an alternative model, the tectonic wedge model, proposed that NE-directed movements observed in Upper Lahul are associated with early northward motion along the South Tibetan detachment (Webb, 2013; Webb et al., 2011; Yin, 2006). Based on structural interference patterns, including the overprinting of NE-verging folds by SW-directed folds in a later stage, other research groups working in the region 

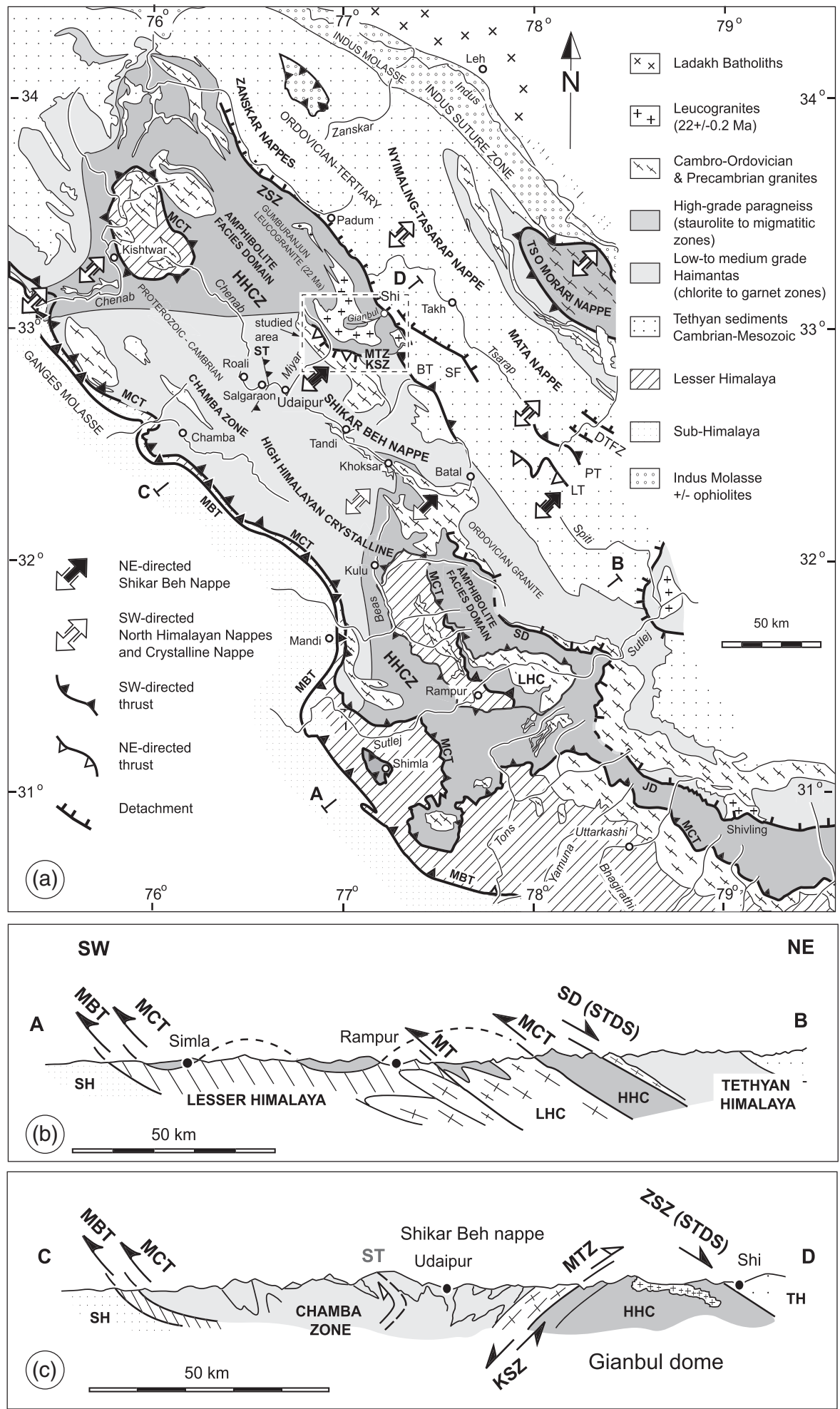

Figure 1. (a) Geological map of the NW Indian Himalaya (compiled after Steck et al., 1999, and Vannay \& Grasemann, 2001). (b) Synthetic cross section of the central Himalaya (modified after Vannay \& Grasemann, 2001). (c) General cross section of the NW Indian Himalaya across the Gianbul dome (modified after Steck et al., 1999). HHC $=$ High Himalayan Crystalline; $\mathrm{NHC}=$ North Himalayan Crystalline; $\mathrm{TH}=$ Tethyan Himalaya; $\mathrm{LH}=$ Lesser Himalaya; $\mathrm{SH}=$ Sub-Himalaya; $\mathrm{MBT}=$ Main Boundary Thrust MCT $=$ Main Central Thrust; STDS $=$ South Tibetan Detachment System; ST = Salgaraon Thrust; ZSZ = Zanskar Shear Zone; MTZ = Miyar Thrust Zone; KSZ = Khanjar Shear Zone; BT = Baralacha La Thrust. 
deduced that the NE-directed structures predate the predominant SW-verging Himalayan deformation (Steck, Spring, Vannay, Masson, Bucher, et al., 1993; Steck, Spring, Vannay, Masson, Stutz, et al., 1993; Steck et al., 1998; Vannay \& Steck, 1995). Similarly, Epard et al. (1995) distinguished two distinct amphibolite-facies structures related to two opposite transport directions along the Kulu-Khoksar transect (Figure 1). Here, the main SW-vergent deformation associated with Early Miocene thrusting along the Main Central Thrust (MCT) superimposes an older set of structures associated with NE-directed movements. These observations lead to the idea that the NE-verging folds and thrust faults in Upper Lahul should be regarded as structures related to early NE-directed Eohimalayan tectonics. The thrust sheet emplaced in that phase is collectively termed the Shikar Beh nappe (e.g., Epard et al., 1995; Steck, Spring, Vannay, Masson, Stutz, et al., 1993) (Figure 1). The debate over the role of the NE-vergent structures and their relation to the SW-vergent transport is significant, as it has kinematic implications for the Himalayan chain as a whole. The occurrence of a NE-directed nappe in the early history of the Himalayan orogeny would imply that the classical view of the Himalayan kinematic evolution manifested by folding and thrusting toward the SW should be reassessed for the NW Indian Himalaya. Despite this fundamental significance, surprisingly little is known about the detailed kinematics and timing of this singular NE-directed transport phase. The present study aims to fill this gap by providing U-Th- $\mathrm{Pb}$ data from metamorphic monazite in the NE-directed Miyar Thrust Zone (MTZ) in Upper Lahul (Pognante et al., 1990; Robyr et al., 2002; Steck et al., 1999). The results reported here provide direct age constraints on the kinematics of NE-directed folding and thrusting in the HHC of NW Indian Himalaya.

\section{Geological Setting}

The HHC corresponds to the metamorphic core zone of the Himalayan range (Figure 1). It consists of a thick sequence of amphibolite facies to migmatitic paragneiss, locally intruded by Ordovician granites and tertiary leucogranites, that thrusts over the low- to medium-grade metasedimentary series of the Lesser Himalaya along the MCT, a major intracontinental thrust developed within the Indian margin during Early Miocene (Coleman, 1998; Frank et al., 1977; Gansser, 1964; Hubbard \& Harrison, 1989; Searle et al., 2008). In most sections across the belt, the HHC is topped to the north by the NE-dipping extensional structures of the South Tibetan Detachment System (STDS; Caby et al., 1983; Burg \& Chen, 1984; Burchfiel et al., 1992) that marks the sharp transition between the HHC high-grade rocks and the weakly metamorphosed sediments of the Tethyan Himalaya (Figure 1). Several studies demonstrated that extension along the STDS and thrusting along the MCT initiated synchronously during Early Miocene at 23 Ma (e.g., Dèzes et al., 1999; Godin et al., 2006; Hodges et al., 1992, 1996). This common view is however challenged by structural and geochronological data revealing that, in central Nepal, the onset of the exhumation of the HHC took place before (middle-late Eocene) the period of MCT and STDS activity (Carosi et al., 2013, 2016; Iaccarino et al., 2017; Montemagni et al., 2020). Movements along both the MCT and the STDS nevertheless suggest a southward tectonically controlled extrusion of the high-grade paragneiss of the HHC (Hodges et al., 1992; Vannay et al., 2004; Vannay \& Grasemann, 2001). This relatively simple geometry is observed in most of the eastern and central Himalayan transects and reflects a kinematic evolution of the Himalayan range mainly controlled by the successive exhumation of large Indian crustal slices that have been detached from the underthrusting Indian plate and sequentially accreted toward the south along major NE-dipping faults and shear zones (e.g., Carosi et al., 2018) (Figure 1). However, the metamorphic record and geologic structures observed in the northwestern part of the Himalaya of India are radically different. One of the characteristics of this region is the lack of high-grade metamorphic rocks in the hanging wall of the MCT, in the frontal part of the range, between the Kulu valley and the downstream part of the Chenab river (Figure 1). In these regions, the hanging wall of the MCT mainly consists of the low- to medium-grade metasediments of the Chamba Zone. By contrast, the amphibolite facies to migmatitic paragneisses, referred in this study to as the HHC Zone (HHCZ) of Zanskar (Robyr et al., 2002), are instead exposed in a more internal part of the orogen as a large-scale dome structure called the Gianbul dome (Dèzes et al., 1999) (Figure 1). This Gianbul dome, which is well exposed along the Miyar and Gianbul valleys, is cored by leucogranite and migmatitic paragneisses symmetrically surrounded by rocks of the sillimanite $+\mathrm{k}$-feldspar, kyanite \pm staurolite, garnet, biotite, and chlorite zone (Robyr et al., 2002) (Figure 2). On the northern limb of the dome, in the Gianbul valley, the contact between the high-grade rocks forming the core of the dome and the low-grade sediments of the Tethyan 


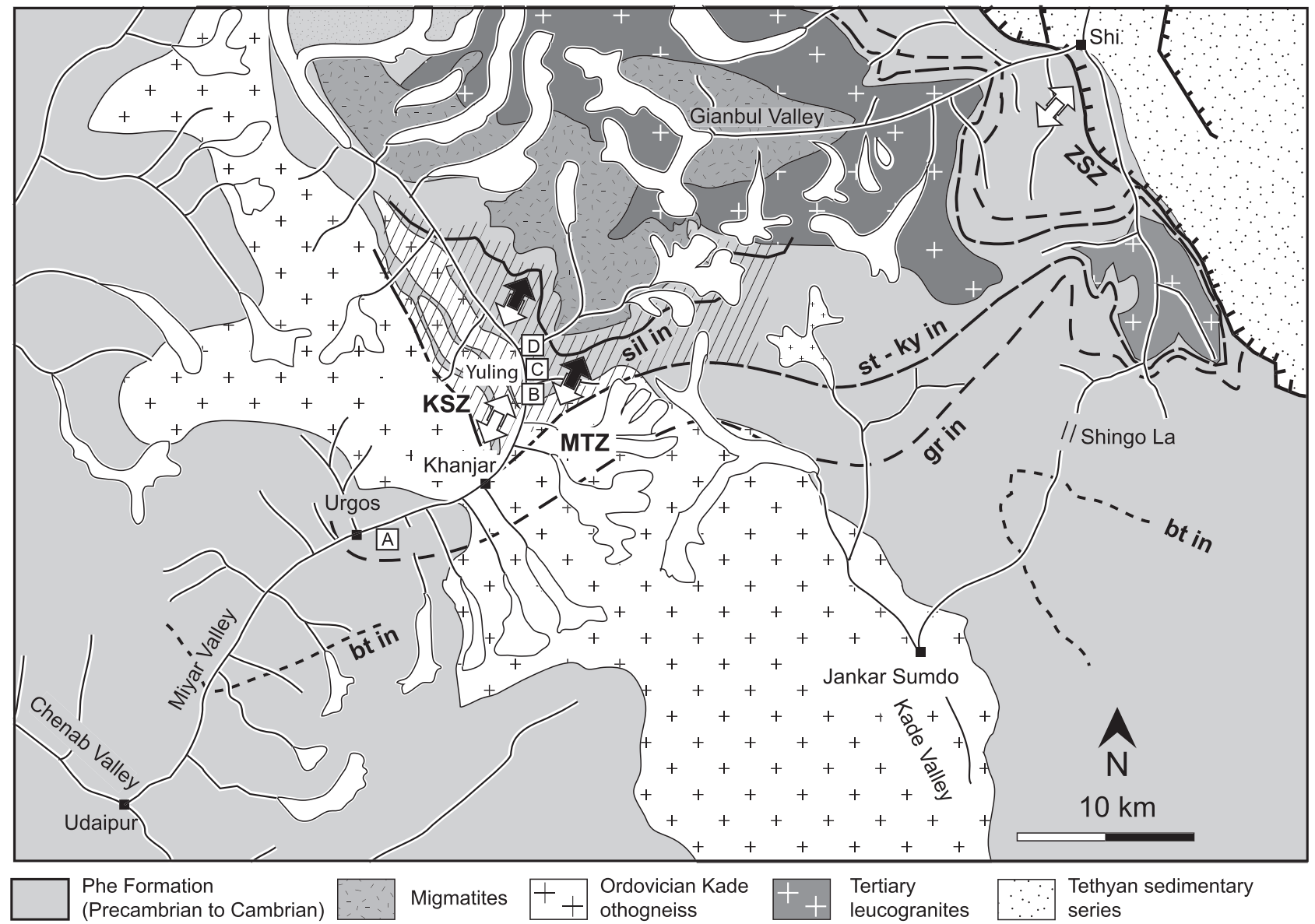

Figure 2. Metamorphic and geologic map of the Gianbul dome area. ZSZ = Zanskar Shear Zone; MTZ = Miyar Thrust Zone; KSZ = Khanjar Shear Zone. The boxes labeled with the letter A-D referred to the location of the sample used for microtectonic analyses and geochronology.

Himalaya corresponds to the NE-dipping Zanskar Shear Zone (ZSZ; Dèzes et al., 1999; Epard \& Steck, 2004; Herren, 1987; Patel et al., 1993), a local equivalent of the STDS. This early Miocene extensional structure initially acted as a thrust zone along which the rocks of the HHC, now forming the northern limb of the dome, were underthrust below the frontal part of the North Himalayan nappes that have affected the sedimentary series of the Tethyan Himalaya (Dèzes et al., 1999; Patel et al., 1993; Schlup et al., 2011). Geochronological results from the northernmost part of the HHCZ of Zanskar established that the prograde metamorphism in this part of the range occurred between 35 and $25 \mathrm{Ma}$ (Sm-Nd in garnet; Vance \& Harris, 1999). Within the ZSZ, a retrograde metamorphic evolution characterized by the successive growing of sillimanite, cordierite, andalusite, and margarite indicates a nearly isothermal retrograde $P-T$ path suggesting that the rocks of the $\mathrm{HHCZ}$ of Zanskar were rapidly exhumed along the extensional structures of the ZSZ (Dèzes et al., 1999). U-Pb dating of monazite from various leucogranitic plutons and dykes in the footwall of the ZSZ indicate that the main extensional shearing along the ZSZ initiated before 22.2 $\pm 0.2 \mathrm{Ma}$ and ceased by $19.8 \pm 0.1-19.3 \pm 0.1 \mathrm{Ma}$ (Dèzes et al., 1999).

The Gianbul dome is delimited along the Miyar valley, on its southern limb, by a major ductile shear zone referred to as the Miyar Shear Zone (Robyr et al., 2002; Steck et al., 1999) (Figures 2 and 3). Initially defined by Pognante et al. (1990) as the Miyar Thrust, this structure marks the transition between the high-grade metamorphic rocks forming the core of the dome and the low- to medium-grade metasediments of the Chamba zone that forms in this region the hanging wall of the MCT (Robyr et al., 2002). Structural fabrics such as sigma clasts, back rotated boudins, or asymmetrical extensional shear bands across the Miyar Shear Zone indicate that this SW-dipping shear zone initially acted as a contractional shear zone with top-to-theNE sense of shear (Figure 3). The shear zone that recorded the NE-vergent structures is referred to as the 




Figure 3. Representative structures from the Miyar Thrust Zone (modified from Robyr et al., 2014). (a) Sigmoidal inclusion trails in garnet from the footwall of the Miyar Thrust Zone. This synkinematic garnet indicates a NE-verging simple shear in the Miyar Thrust Zone. (b and c) Mylonitic amphibolite-facies paragneisses and sandstones with sigma-type quartz porphyroclasts showing top-to-NE shear sense (lower part of the Miyar Thrust Zone). (d and e) Extensional shear bands of the normal Khanjar Shear Zone overprinting the main foliation in the migmatitic zone. (f) Panoramic view of the Miyar Thrust Zone.

MTZ (Robyr, 2002; Robyr et al., 2006, 2014; Steck et al., 1999). The MTZ represents only one among other structures in Upper Lahul showing that NE-directed crustal deformation affected the Indian continental crust during the Himalayan orogeny. These NE-directed structures have been interpreted as reflecting the emplacement of a NE-directed thrust sheet collectively termed the Shikar Beh nappe (Epard et al., 1995; Robyr, 2002; Robyr et al., 2002, 2014; Steck, 2003; Steck, Spring, Vannay, Masson, Stutz, et al., 1993; Steck et al., 1999; Vannay \& Steck, 1995). The similarities in shear sense (top-to-the-NE) between the MTZ and the ZSZ led other authors to see in the NE-directed structures observed across the MTZ an evidence to refer the MTZ as the folded equivalent of the ZSZ (Dèzes, 1999; Webb et al., 2007, 2011; Yin, 2006).

\section{The Miyar Shear Zone and the Shikar Beh Nappe}

In the Upper Lahul region, north of Udaipur, the Miyar-Gianbul valleys transect represents an excellent natural cross section through the structure and metamorphic zonation of the HHCZ of SE Zanskar (Figure 2). The geological setting of the Miyar Valley transect is summarized in the next section, whereas a more detailed account is given in the following published articles: Pognante et al. (1990), Steck et al. (1999), Robyr (2002), Robyr et al. (2002), Robyr et al. (2006), Robyr et al. (2014), Goswami-Banerjee and Robyr (2015), and Horton et al. (2015).

Moving upsection along the Miyar Valley, from the village of Udaipur toward the north, the metapelites of the HHCZ preserved a typical Barrovian metamorphism characterized by a gradual succession of chlorite, biotite, garnet, kyanite \pm staurolite, sillimanite $+\mathrm{k}$-feldspar, and migmatite zones (Figure 2). Pressure 
and temperature $(P-T)$ estimates indicate peak conditions evolving from $\sim 550^{\circ} \mathrm{C}$ and 6 kbar in the garnet zone to $\sim 800^{\circ} \mathrm{C}$ and $8 \mathrm{kbar}$ in the sillimanite-migmatite zone (Robyr et al., 2002). The main tectonic structure in the Miyar Valley corresponds to the Miyar Shear Zone that separates the greenschist-facies metasediments of the Chamba zone to the SW from the amphibolite facies to migmatite paragneiss of the HHCZ to the NE that form in this region the southeasternmost limit of the Gianbul dome. The Miyar Shear Zone consists of an $\sim 3 \mathrm{~km}$ wide and $1 \mathrm{~km}$ thick SW-dipping shear zone containing a wide range of tectonic structures including sheath folds, sigma clasts, shear bands, or back rotated boudins that all show a top-to-the-NE sense of shear. The development of sigmoidal inclusion trails in syntectonic garnets prophyroblasts relates the growth of the metamorphic assemblage with NE-directed tectonic movements (Robyr et al., 2002, 2014). Consequently, the Miyar Shear Zone, which initially acted as a thrust zone, the MTZ, could represent the synmetamorphic basal thrust of a NE-directed nappe that is also responsible for the burial and high-grade metamorphism of the HHCZ of SE Zanskar on the southern part of the Gianbul dome.

Across the MTZ, the NE-verging contractional structures are superimposed by SW-dipping extensional shear bands and back rotated boudins that indicate a top-to-the-SW sense of shear. These observations reveal that the MTZ was reactivated as a ductile zone of extension referred to as the Khanjar Shear Zone (KSZ) (Robyr et al., 2002; Steck et al., 1999). This structural interpretation is supported by the petrographic investigations. In the Miyar Valley, this extensional event is marked by high temperature-low pressure retrograde conditions superposed on the prograde Barrovian-type metamorphism. Indeed, in the metapelites from the kyanite zone, within the shear zone, the successive crystallization of sillimanite, growing as fine-grained fibrolite at the expense of kyanite, of cordierite as postkinematic poikiloblast surrounding kyanite and of andalousite as stable aluminosilicate reveals a retrograde evolution characterizing a nearly isothermal decompression (Robyr et al., 2002). These observations indicate that the Miyar Shear Zone acted as a NE-directed synmetamorphic thrust, the MTZ, along which the rocks now forming the HHCZ of Zanskar were underthrust below the Chamba zone before being reactivated as a SW-directed ductile zone of extension, the KSZ, during the exhumation of the Gianbul dome. Monazite dating from migmatite in the footwall of the Miyar Shear Zone and from various undeformed leucogranitic dykes cross cutting the extensional structures of the KSZ indicate that ductile shearing along this structure was active between 26 and $23 \mathrm{Ma}$ (Horton et al., 2015; Robyr et al., 2006, 2014).

A major feature of the tectono-metamorphic evolution of the HHCZ in the Miyar valley is that the main phase of metamorphism and tectonism relates to NE-directed thrusting. This is clearly in contrast with the southward thrusting and folding that has been predominant in the Himalaya since continental collision. However, this unusual vergence is consistent with other structures observed in Upper Lahul and Spiti regions including the Lagudarsi La thrust, the Tandi syncline, and the MTZ (Epard et al., 1995; Horton et al., 2015; Robyr et al., 2002; Steck, Spring, Vannay, Masson, Bucher, et al., 1993; Steck et al., 1999; Vannay \& Steck, 1995; Wyss et al., 1999). These structures constitute major tectonic structures that all indicate that the earliest phase of deformation in these regions results from northward tectonic movements. The SW-dipping orientation and the occurrence of numerous top-to-the-NE shear sense indicators within the MTZ suggest that this shear zone corresponds to the frontal thrust of a nappe sourced from the southwest.

Additionally, mineral textures and microstructures combined with thermobarometric data indicate that the overburden generated by this early NE-directed tectonic phase was thick enough to induce medium-pressure regional metamorphism up to partial melting grade in the Upper Lahul region (Epard et al., 1995; Robyr et al., 2002). These results argue for the emplacement of a NE-directed crustal thickening phase in an earlier stage of the Himalayan orogeny. This interpretation is in line with the model advanced by Steck, Spring, Vannay, Masson, Bucher, et al. (1993) and Steck, Spring, Vannay, Masson, Stutz, et al. (1993), that is, the NE structures observed in the Upper Lahul represent a set of structures reflecting the emplacement of a NE-directed nappe that they termed the Shikar Beh nappe.

In order to constrain the kinematics and timing of the MTZ and to test the hypothesis of an early Eocene nappe emplacement, samples collected across the Miyar Shear Zone were selected for microstructural analyses and monazite U-Th- $\mathrm{Pb}$ geochronology.

Along the pelitic sequence of the Miyar Valley, the crystallization of the first metamorphic monazite occurs simultaneously with the growth of staurolite at about $600^{\circ} \mathrm{C}$ (Goswami-Banerjee \& Robyr, 2015). Therefore, 

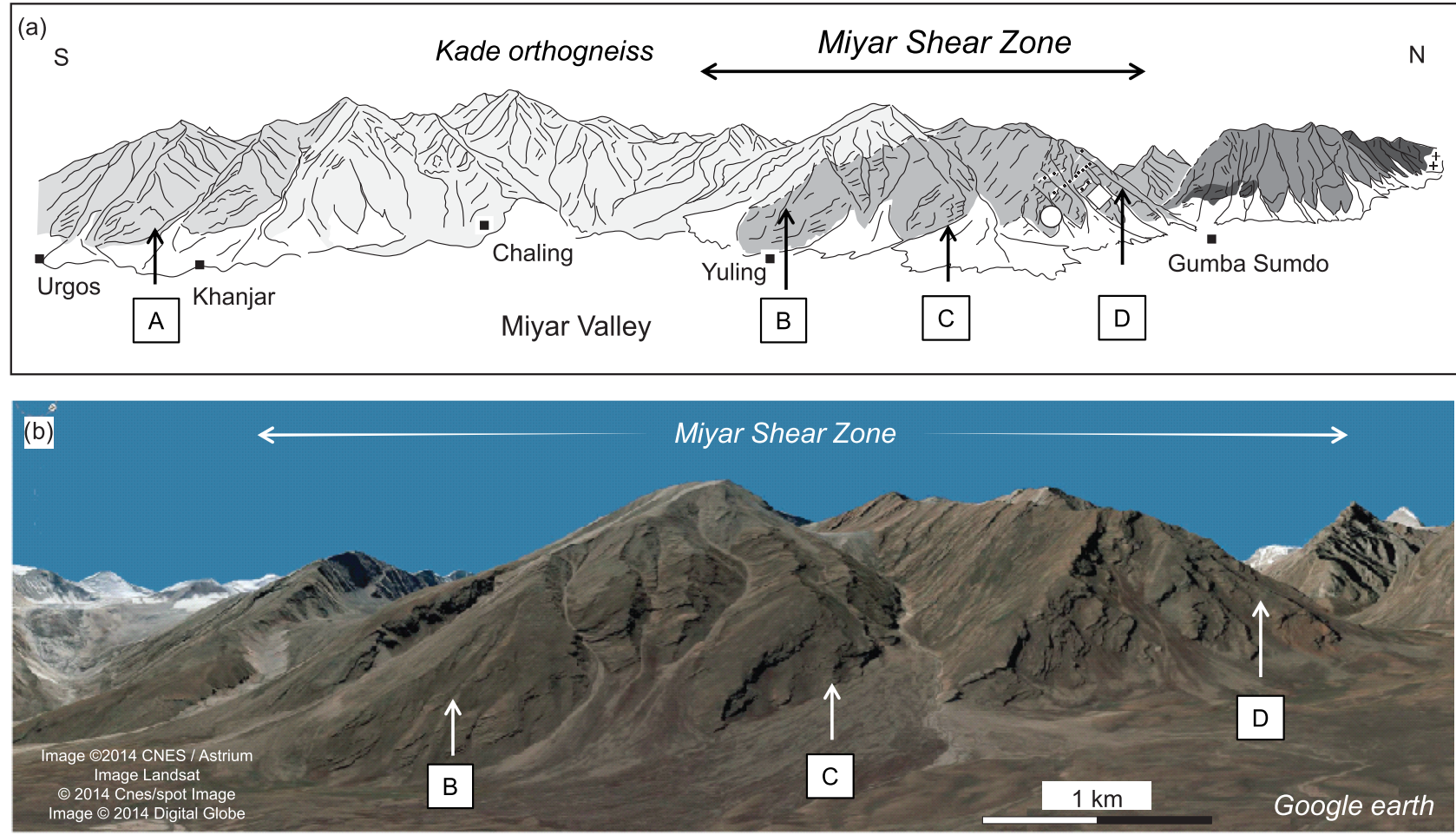

Figure 4. (a) Panoramic view of the Miyar Shear Zone from Urgos to Gumba Sumdo. The labeled boxes referred to the location of the samples used for microtectonics analyses and for geochronology. The different location corresponds to the sampling localities of the following samples used for microtectonics analyses and for geochronology: $\mathrm{A}=\mathrm{RM}$ 02-4; $\mathrm{B}=\mathrm{RM}$ 98-45, RM 99-56, RM 99-58, and RM 99-59; $\mathrm{C}=\mathrm{RM}$ 98-66 and RM 98-69; D = RM 98-77. The circle and diamond symbols correspond to the sampling location of the Samples RM 98-61 and RM 98-71, respectively. (b) Closer view of the Miyar Shear Zone.

assuming that U-Th- $\mathrm{Pb}$ ages for monazite reflect monazite crystallization ages (Cherniak et al., 2004; Gregory et al., 2012; Harrison et al., 2002; Parrish, 1990; Smith \& Giletti, 1997), then dating monazite in the staurolite zone dates the crystallization of staurolite.

\section{Porphyroblast-Matrix Relation Across the Miyar Shear Zone}

In order to connect monazite crystallization, and consequently the monazite ages, with the deformation phases, a study of the crystallization sequence of the main mineral phases was carried out to link staurolite growth and deformation phases. For this purpose, samples from the hanging wall (Figure 5), the structurally upper part (Figure 6), middle part (Figure 7), and lower part (Figure 8) of the Miyar Shear Zone were selected for microstructural analyses (see sample location in Figure 4). A summary of the main deformation stages and associated mineral parageneses and microstructures is provided in Figure 8.

\subsection{Hanging Wall of the MTZ}

The sample selected in the hanging wall consists of a metapelite collected within the metamorphic garnet zone near the village of Urgos (Figures 1 and 2). Metapelites in garnet zone are characterized by a mineral assemblage of Qtz $+\mathrm{Pl}+\mathrm{Bt}+\mathrm{Ms}+\mathrm{Grt} \pm \mathrm{Chl}$ with allanite as rare earth element (REE) accessory phase. In the sample from the garnet zone, the main foliation (S2) is defined by the preferred orientation of biotite and muscovite crystals that warp around garnet porphyroblasts. By place, the main foliation is folded, leading to the development of a crenulation cleavage S3. Local retrograde reactions of garnet and biotite to chlorite testify a late partial reequilibration at lower metamorphic grades (Figure 5).

The core region of the garnet porphyroblasts preserves an S1 foliation that recurrently forms sigmoidal inclusion trails. By contrast, the garnet rims are depleted in inclusions compared to the core region. Furthermore, moving from core to rim, the geometry of the inclusion trails evolves from a sigmoidal pattern toward a 

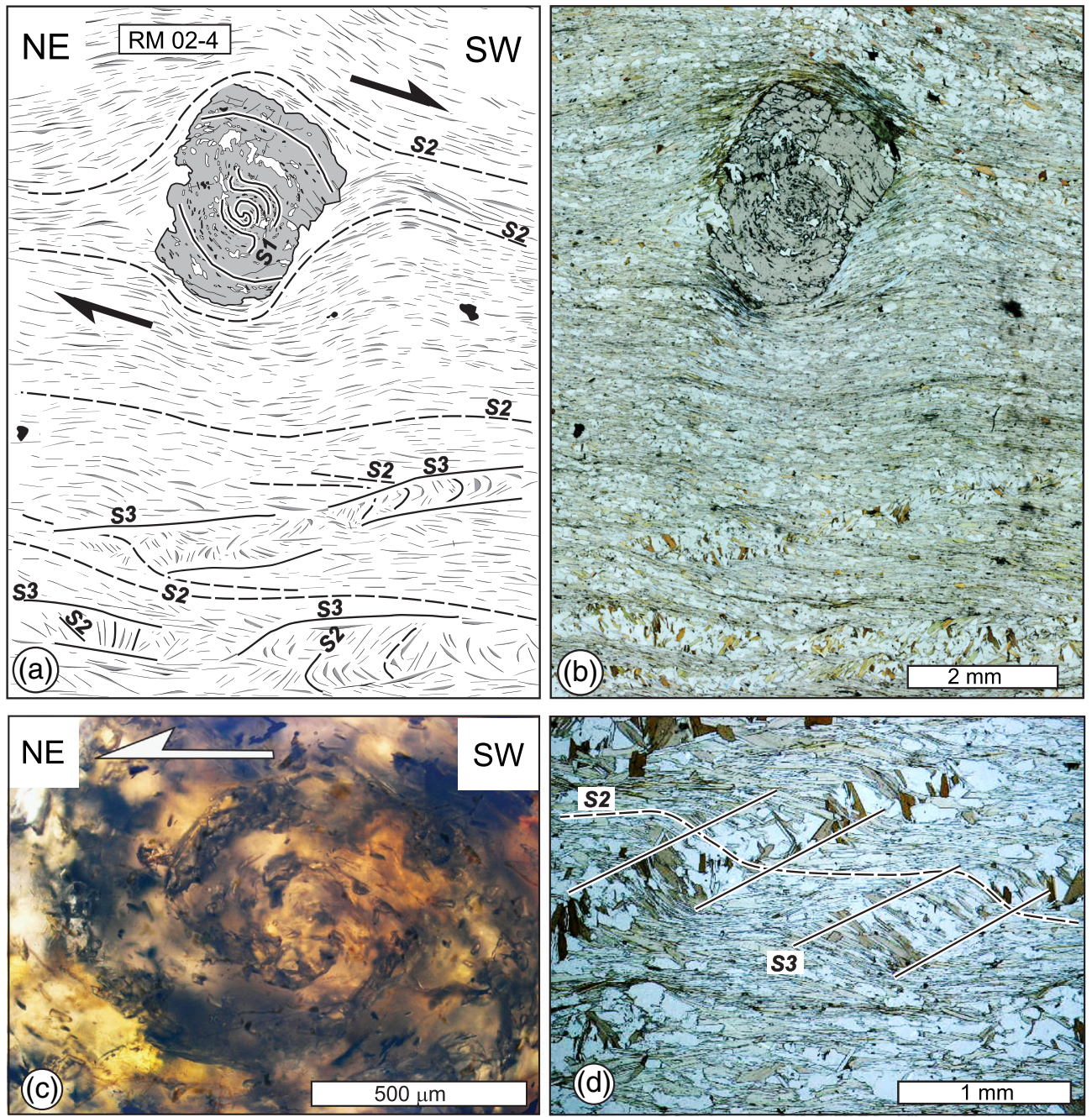

Figure 5. Selected petrographic observations from a garnet-bearing paragneiss from the hanging wall of the MTZ: (a) sigmoidal inclusion trails (S1) in a garnet indicating a growth associated with NE-verging simple shear. The garnet is wrapped by an S2 foliation, which corresponds here to the main schistosity. Shear sense criteria in the matrix indicate an opposite top-to-the-SW movement. (b) Photomicrograph of the thin section illustrated in (a). (c) Photomicrograph of a D1 syntectonic garnet from the same sample. Shear sense criteria deduced from the helicitic inclusion trails indicate top-to-the-NE rotation of more than $180^{\circ}$. (d) Photomicrograph showing the relation between the main schistosity S2 and the crenulation cleavage S3.

slightly curved shape indicating a change in the behavior of the garnet porphyroblast during its growth. The sigmoidal inclusion trails observed in the core region indicate a simultaneous growth and northward rotation of the porphyroblast during a first stage of garnet crystallization. By contrast, the inclusion pattern in the rim indicates that, in the final stage of crystallization, the garnet statically overgrew mica caps developed around the garnet. The main schistosity observed in the matrix is deflected around the garnet crystal and exhibits a well-developed strain cap on both sides of the garnet. The development of asymmetric pressure shadows on both sides of the porphyroblasts indicates that the formation of the main schistosity (S2) was accompanied by top-to-the-SW shearing. These observations reveal that two distinct phases of deformation are responsible for the development of the schistosity. During the crystallization of the garnet porphyroblast, a first phase of deformation accompanied by NE-directed shearing generated a first schistosity S1 now preserved as inclusion trails in garnet. This was followed by a second phase of SW-directed deformation accountable for the development of the main schistosity. Subsequently, an S3 cleavage developed, folding locally the S2 main foliation (Figures 5 and 9). Peak $P$ - $T$ conditions for garnet 

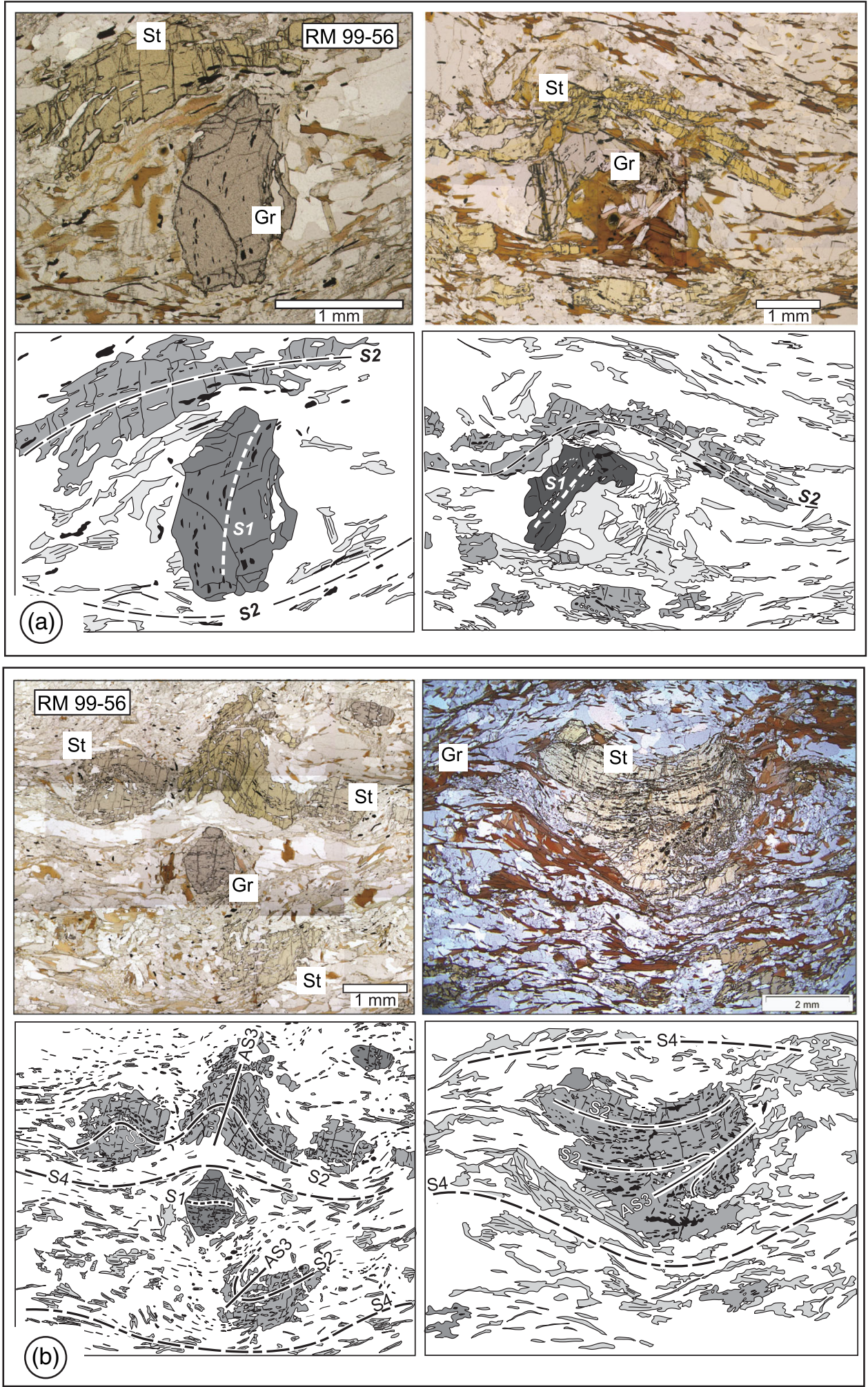

Figure 6. Selected photomicrographs of a staurolite-garnet-bearing sample from the upper part of the MTZ. (a) Porphyroblast of garnet containing an S1 internal foliation that is clearly in discontinuity with respect of the S2 foliation observed in the staurolite porphyroblasts. (b) Folded internal S2 schistosity in staurolite porphyroblast indicating the crystallization of staurolite occurred statically on the S2 schistosity already folded by the D3 deformatin phases. 

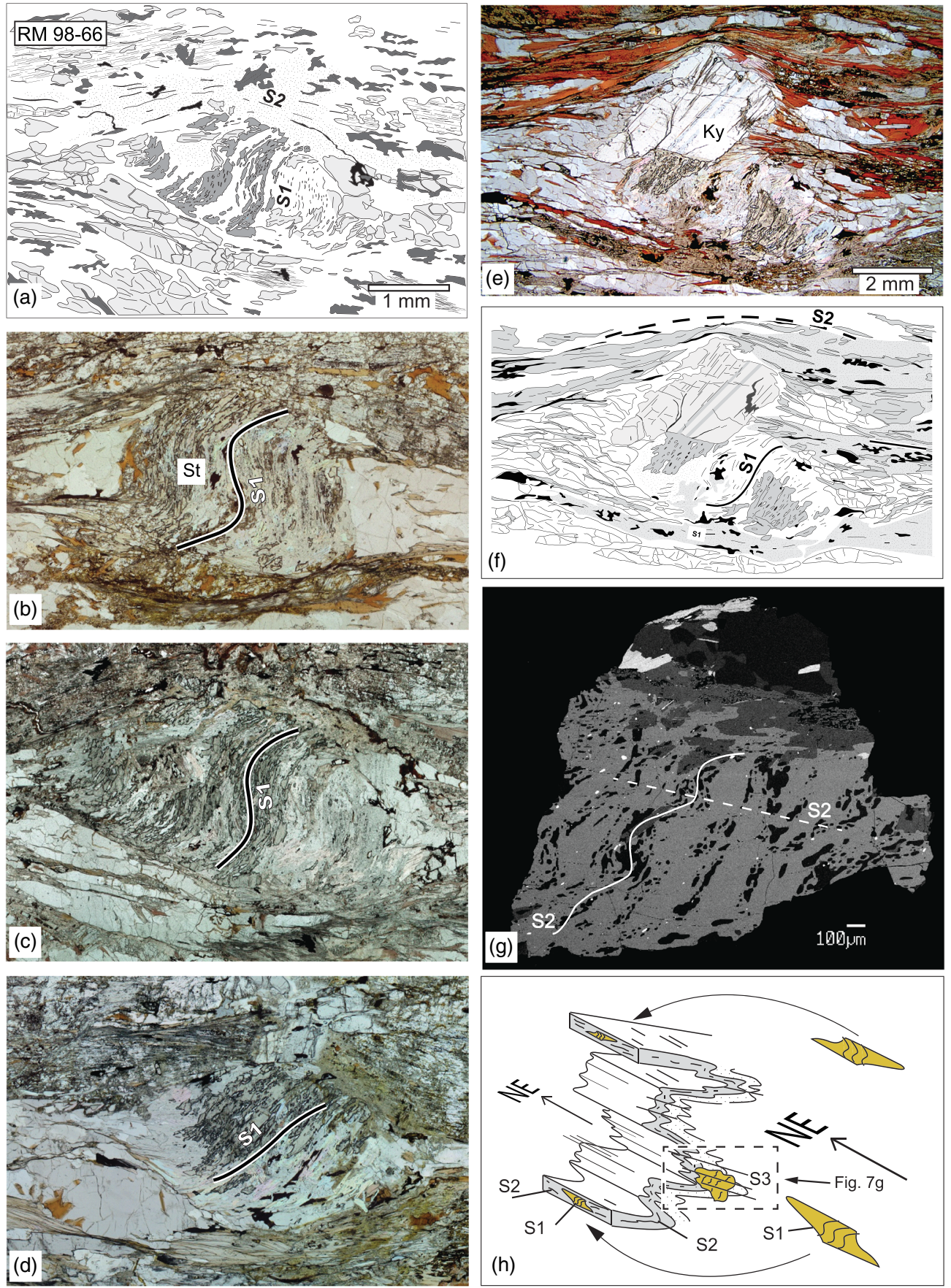

Figure 7. (a) Synkinematic staurolite in a kyanite-bearing metapelite from the middle part of the MTZ. (b-d) Evolution of the geometry of the S1 internal foliation along the rotation axis of the staurolite during its growth. The gradually decreasing amplitude of the spiral from core to rim indicates a simultaneous growth and rotation of the straurolite crystal. (e and f) Crystal of kyanite from the same sample growing at the expense of staurolite. The crystal of staurolite is wrapped by the main schistosity indicating a pretectonic growth of the staurolite with respect to the development of the main schistosity. ( $\mathrm{g}$ ) BSE image of a staurolite from the same sample containing crenulated inclusion trails. This observation reveals two generations of staurolite crystal in this sample. The second generation grows statically on the $\mathrm{S} 3$ foliation as illustrated in (h).

crystallization (D1) were estimated between $506 \pm 49^{\circ} \mathrm{C}$ and $525 \pm 39^{\circ} \mathrm{C}$ at $6 \pm 0.9$ and $5.7 \pm 1 \mathrm{kbar}$, respectively (samples RM 98/6 and AS 98/60 in Robyr et al., 2002) indicating a burial depth of about $20 \mathrm{~km}$ assuming a lithostatic gradient of $0.27 \mathrm{kbar} / \mathrm{km}$. 

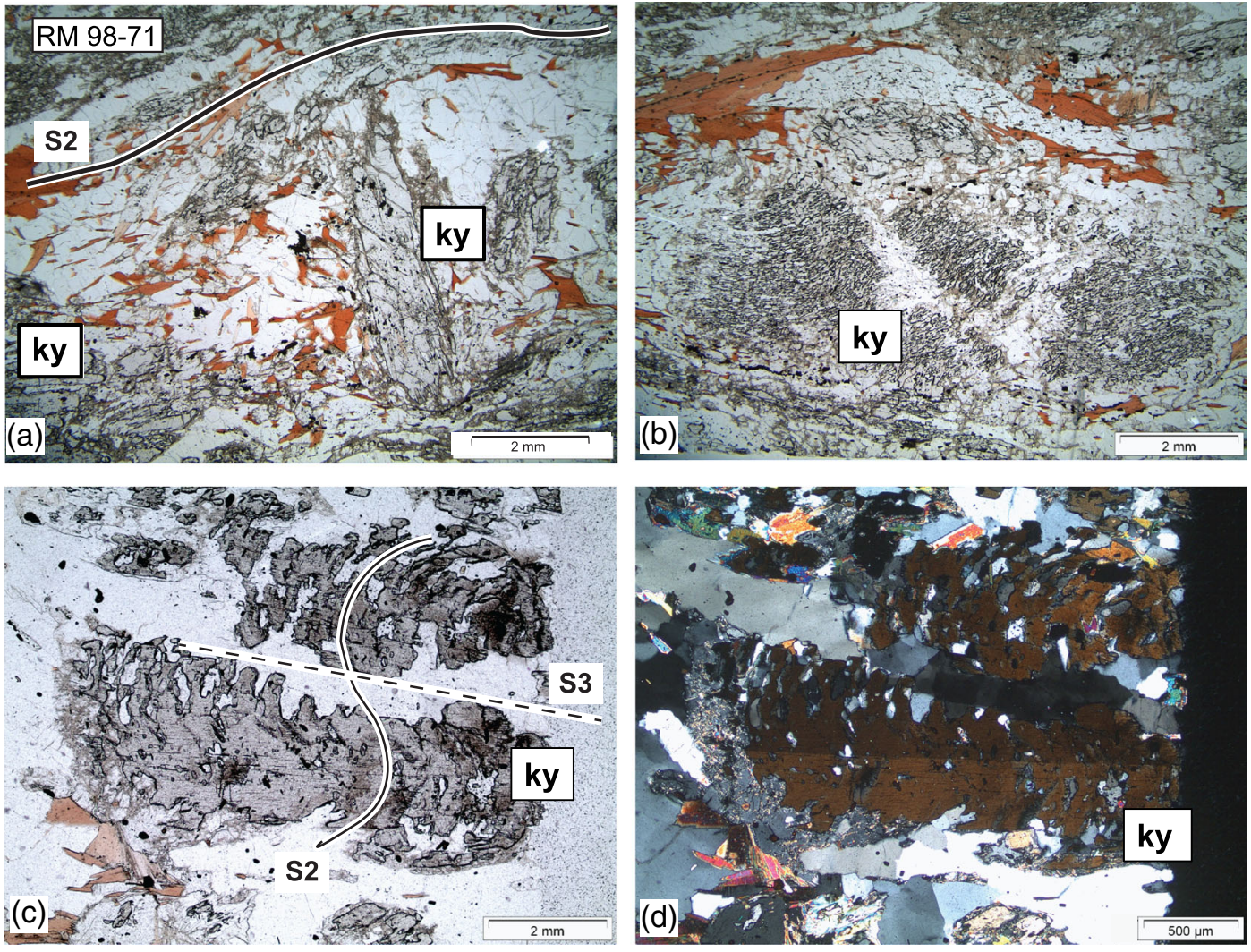

Figure 8. Selected photomicrographs of a kyanite-garnet-bearing sample from the bottom part of the MTZ. (a) Prismatic millimeter long kyanite crystal oriented perpendicular to the main foliation belonging to the first generation of kyanite. (b-d) Second generation of kyanite crystal containing crenulated inclusion trails.

\subsection{Upper Part of the MTZ}

The structurally upper part of the MTZ coincides with the occurrence of staurolite in the metasediments of the HHC along the Miyar Valley near the pasture ground named Yuling (Figure 2). Here, the metapelites contain the peak assemblage of $\mathrm{Qtz}+\mathrm{Pl}+\mathrm{Bt}+\mathrm{Ms}$ associated with either $\mathrm{Grt}+\mathrm{St}+\mathrm{Ky}, \mathrm{Ky}+\mathrm{St}$, or solely garnet depending on the bulk rock composition. Garnet frequently preserves an internal schistosity S1 that is discontinuous with respect to the main foliation observed within the matrix (Figure 6). This observation indicates that garnet nucleation and growth in this sample predate the development of the main foliation (S2). The foliation in the matrix is marked by biotite, muscovite, kyanite, and staurolite. The main foliation S2 is bent around the garnet porphyroblasts. Staurolite regularly preserves an internal schistosity as well. The internal schistosity preserved in staurolite is also deflected around the garnet grains (Figure 6a, bottom left) indicating that the foliation preserved in staurolite corresponds to the S2 schistosity. Furthermore, the internal schistosity (S2) in staurolite defines folds indicating that staurolite crystallized after the folding of the schistosity S2. As a consequence, staurolite grew on an S2 schistosity that have been already deformed by a D3 deformation phase (Figure 6b). The D3 deformation phase is expressed only through the folding of the S2 foliation and does not generate a S3 schistosity. Furthermore, the main matrix foliation is deflected around the staurolite porphyroblast implying that a foliation S4 developed in the rocks after the crystallization of staurolite. It consequently appears that the main matrix foliation corresponds to the locally parallelized S2 and S4 foliation. These microstructural observations clearly show that staurolite grew statically during an intertectonic period between the D3 and D4 deformation phases (Figure 9).

Calculated equilibrium phase diagrams indicate that staurolite is stable in these rocks for temperature between $580^{\circ} \mathrm{C}$ and $620^{\circ} \mathrm{C}$ (Goswami-Banerjee \& Robyr, 2015). 

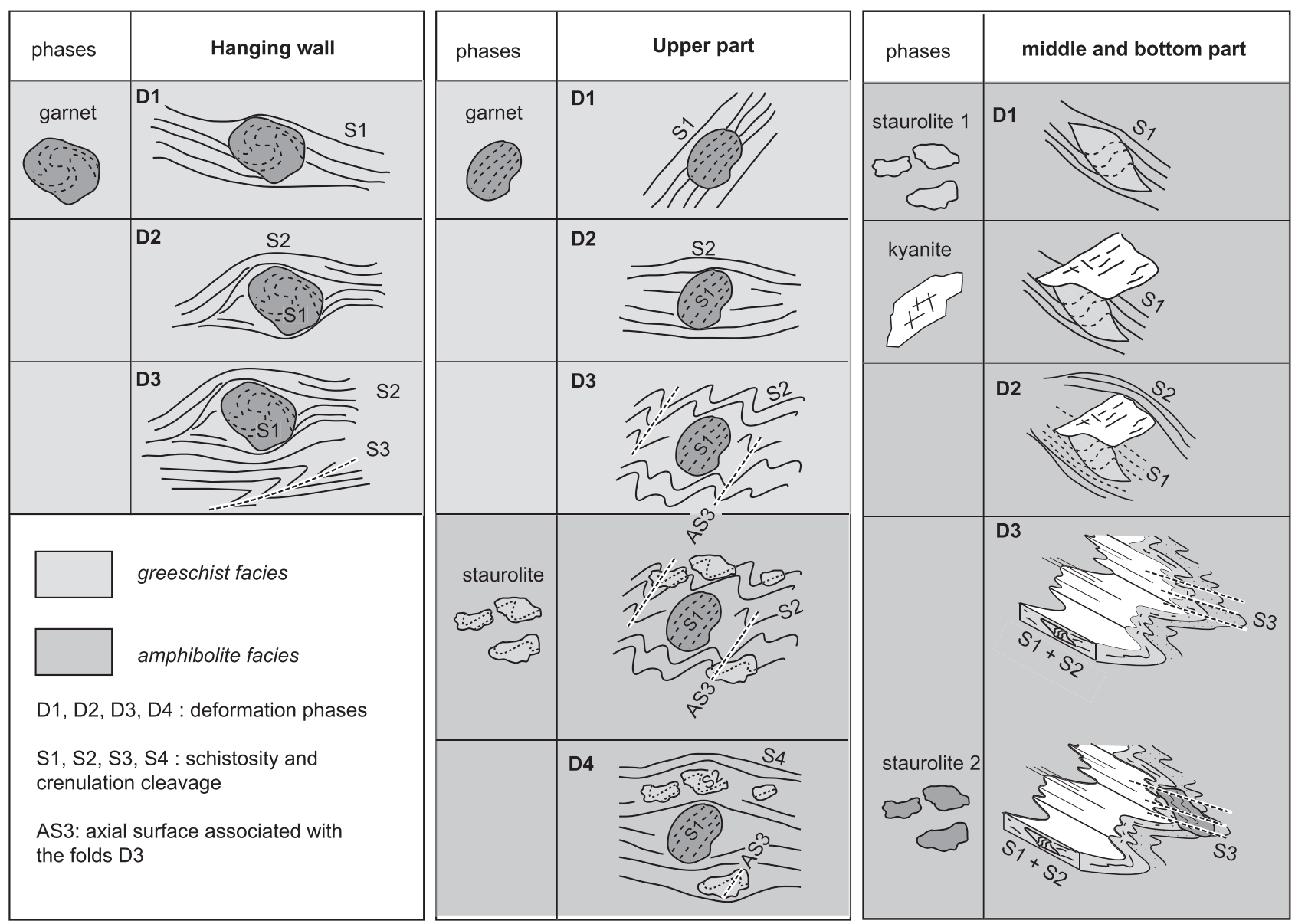

Figure 9. Relative chronology of the tectonic events, textures, and metamorphism for the samples of the hanging wall, the upper, middle, and bottom parts of the MTZ.

\subsection{Middle Part of the MTZ}

The metapelites collected in the middle part of the shear zone contain the assemblage of Qtz $+\mathrm{Pl}+\mathrm{Bt}+$ $\mathrm{Ms}+\mathrm{St}+\mathrm{Ky}$ (Figure 7). The first phase of deformation in these samples corresponds to the development of a first schistosity S1 visible as sigmoidal inclusion trails within staurolite porphyroblasts (Figure 7a). A syntectonic staurolite growth during D1 is testified by the gradually decreasing amplitude of the spiral from core to rim along the symmetry axis of the spiral (Figures $7 b-7 d$ ). The kyanite grains grew at the expense of staurolite and are wrapped by the main schistosity S2 (Figure 7e). This observation indicates that the porphyroblasts of kyanite crystallized statically between the deformation phases D1 and D2. A crenulation cleavage S3 subsequently developed within these rocks leading to the folding of the S2 foliation and the development of a NE-SW lineation of crenulation (Figure $7 \mathrm{~g}$ ). As this crenulation phase is responsible for the folding of the earlier schistosities around a fold axis parallel to the stretching lineation observed on S1, the establishing of a shear sense criteria based on the geometry of the S1 sigmoidal inclusion trails becomes impractical. Indeed, the spiral geometry defines opposite shear directions depending on the location of the sampling with respect to the fold axes D3 (Figure 7h).

Finally, on section perpendicular to the lineation of crenulation, the occurrence of staurolite showing an inclusion pattern mimicking the crenulation cleavage indicates that a second generation of staurolite crystallized in a late stage in these rocks (Figure 7g).

\subsection{Bottom Part of the MTZ}

Kyanite-rich metapelitic layers are observed within the structurally deepest levels of the shear zone. In these layers, two generations of kyanite can be distinguished. The first generation corresponds to prismatic 
millimeter long kyanite crystal oriented perpendicular to the main foliation (Figure 8). Unfortunately, no clear argument permits to decipher between a syn- or post-S1 tectonic growth. In any case, the deflection of the main foliation around the kyanite crystals and the strain cap of top of the kyanite testify that the kyanite growth occurred prior to the formation of the main foliation that has to be seen as an S2 foliation.

A second generation of kyanite crystal frequently contains inclusion trails revealing that it statically grew on a crenulated foliation (Figures $8 \mathrm{c}$ and $8 \mathrm{~d}$ ). This observation indicates that the main foliation S2 was crenulated by a D3 deformation phase before the crystallization of the second generation of kyanite.

Garnet growth modeling performed on one sample from the bottom part of the MTZ indicates growth conditions of $560^{\circ} \mathrm{C}$ and $6.5 \mathrm{kbar}$ for the core and $660^{\circ} \mathrm{C}$ and $9 \mathrm{kbar}$ for the rim (sample RM 9877 in GoswamiBanerjee \& Robyr, 2015).

\section{Microstructural Interpretations}

The microstructural observations across the MTZ reveal a polymetamorphic history characterized by diachronic growth of staurolite (Figure 9). In both, the hanging wall and the upper part of the MTZ, a D1 phase of deformation occurs under greenschist-facies conditions underlined by the growth of garnet crystals in both locations. The greenschist-facies conditions correspond to the metamorphic peak conditions for the samples of the hanging wall of the MTZ near the village of Urgos. By contrast, the greenschist-facies assemblages are superimposed by amphibolite-facies conditions in the upper part of the MTZ. Here, the peak metamorphic conditions, defined by the growth of staurolite and kyanite, have been recorded after the D3 deformational event. Goswami-Banerjee and Robyr (2015) demonstrated meticulously that along the pelitic sequence of the Miyar Valley, staurolite crystallized contemporaneously with monazite (Goswami-Banerjee \& Robyr, 2015). This observation, which corroborates similar observations in the central Alps (Janots et al., 2008), implies that dating monazite is equivalent to dating staurolite crystallization in these rocks as they formed at similar $P$ - $T$ conditions. Therefore, dating monazite in the upper part of the MTZ signifies dating the intertectonic episode between the phase of deformations D3 and D4.

Structurally deeper across the MTZ, in the middle and bottom parts of the MTZ, all phases of deformation occurred under amphibolite-facies conditions. In these two sampling sites, two stages of staurolite and kyanite growth are observed. For both minerals, staurolite and kyanite, a first generation of crystal grew during the first phase of deformation, and a second generation of crystal grew statically after the third phase of deformation. Yet a question remains about the relative timing of growth of the two generations of staurolite crystals. Whereas the first generation of staurolite grew statically in a relatively late phase of the tectono-metamorphic history in the upper part of the MTZ, the growth of the first staurolite is syntectonic with respect to the first phase of deformation in middle part of the MTZ.

This observation leads to two possible interpretations: (a) The phases D1 in all localities correspond to the same event, and then staurolite in the middle part of the MTZ is contemporaneous with garnet in upper part and in the hanging wall of the MTZ. This scenario implies that the first staurolite in the upper part would be contemporaneous with the second generation of staurolite in the middle part of the shear zone, and (b) the samples collected in the upper part and the middle part of the MTZ underwent a distinct tectono-metamorphic history. To resolve this issue, monazite dating was conducted on samples through the MTZ.

\section{Monazite Compositional Zoning and Reaction Sequence}

A detailed study of the textural and chemical evolution of allanite and monazite along the Miyar Valley section demonstrated that monazite is essentially metamorphic along this section (Goswami-Banerjee \& Robyr, 2015). Indeed, along the Miyar Valley, allanite is the stable REE accessory phase in the chlorite to garnet zones, whereas monazite appears to be the main REE accessory phase at higher metamorphic grade in the staurolite, kyanite, and sillimanite zones. Within the staurolite zone, Goswami-Banerjee and Robyr (2015) documented thoroughly that allanite and monazite coexist in inclusion in staurolite porphyroblasts, whereas only monazite is stable in the matrix assemblage. This observation indicates that, during staurolite crystallization, allanite reacted to form metamorphic monazite constraining thus the temperature of crystallization of monazite to $\sim 600^{\circ} \mathrm{C}$ (Goswami-Banerjee \& Robyr, 2015). Similar conclusions were reached for sample distributed along Barrovian-type metamorphic gradients (e.g., Janots et al., 2008). 
Back-scattered electron images (BSE) and X-ray compositional maps for La, Ce, Y, and Th were obtained with a JEOL 8230F microprobe at the University of Lausanne, using a beam current of $400 \mathrm{nA}$ and an accelerating voltage of $15 \mathrm{kV}$, with a dwell time of $100 \mathrm{~ms}$ (Figures 10 and 11). Although X-ray intensity maps for Th and Y show minor variation in Samples RM 98-69 and RM 98-77, quantitative microprobe data for the same monazite grains available in Goswami-Banerjee and Robyr (2015) reveal that monazite is largely chemically homogeneous across the MTZ. More importantly, the BSE and X-ray compositional maps do not show any patchy zoning or any distinct growth zones in trace elements suggesting that no major change occurred during monazite growth (Zhu \& O'Nions, 1999). These observations indicate that the monazite grains were not affected by overgrowth or replacement by dissolution-precipitation during subsequent metamorphic stages. Additional X-ray compositional maps for La, Ce, Y, and Th presented in Goswami-Banerjee and Robyr (2015) emphases the chemical homogeneity and similarity between monazite included in staurolite and those from the matrix. This result confirms that the two families of monazite crystallized under the same conditions ( $P, T$, and reactive bulk composition), namely, the conditions prevailing during staurolite crystallization (Goswami-Banerjee \& Robyr, 2015). This set of observations and data clearly indicates that the crystallization of monazite across the MTZ is directly linked to the prograde Barrovian-type metamorphism observed along the Miyar Valley section. Therefore, dating monazite across the MTZ signifies constraining the timing when each rock reached the $\sim 600^{\circ} \mathrm{C}$ isotherm.

\section{Monazite Geochronology}

$\mathrm{U}-\mathrm{Th}-\mathrm{Pb}$ ages of monazite from samples distributed across MTZ were obtained on polished thin sections by laser ablation inductively coupled plasma mass spectrometry using a GeoLas Pro $193 \mathrm{~nm}$ ArF excimer laser ablation system (Lambda Physik, Germany) combined with an ELAN DRC-e quadrupole inductively coupled plasma mass spectrometry housed at the Institute of Geological Sciences, University of Bern. Ablation experiments of unknowns and standards were carried out in spot mode under fixed laser operating conditions: surface energy density of $2.5 \mathrm{~J} \cdot \mathrm{cm}^{-2}$, repetition rate of $9 \mathrm{~Hz}$, and laser diameter of $16 \mu \mathrm{m}$ (see Burn et al., 2017, for the detailed analytical conditions). Monazite G7 (Scherrer et al., 2002) was used as a primary standard and monazite FC1 (Horstwood et al., 2003) as a secondary standard. The data reduction was performed using Iolite 2.5 software (Paton et al., 2011) and the Petrus and Kamber (2012) VizualAge data reduction scheme. The uncertainty propagation method built into Iolite was used to calculate the ${ }^{206} \mathrm{~Pb} /$ ${ }^{238} \mathrm{U},{ }^{207} \mathrm{~Pb} /{ }^{235} \mathrm{U},{ }^{207} \mathrm{~Pb} /{ }^{206} \mathrm{~Pb}$, and ${ }^{208} \mathrm{~Pb} /{ }^{232} \mathrm{Th}$ ratios and final dates as well as their relative uncertainties. Results for the monazite U-Th- $\mathrm{Pb}$ ages are summarized in Figures 11 and 12 and presented as Tera-Wasserburg concordia diagrams. Lower intercept ages were calculated and used in the text as monazite from each sample contains variable (low) fractions of common lead. Age calculations, weighted averages, lower intercept ages, and concordia diagrams were obtained using IsoplotR (Vermeesch, 2018). The data set of the U-Th- $\mathrm{Pb}$ dates (Tables $\mathrm{S} 1$ and $\mathrm{S} 2$ ) and the analytical conditions are available in the supporting information. BSE images of analyzed monazite crystals representative of the crystals dated are presented in Figure 11. The BSE images do not reveal significant zoning in the analyzed monazites. The chemical characteristics of monazite for each metamorphic zone are provided and discussed in Goswami-Banerjee and Robyr (2015).

\subsection{Upper Part of the MTZ}

Three monazite bearing samples (RM 98-45, RM 99-58, and RM 99-59) were collected in the staurolitekyanite zone at the top of the MTZ (Locality B; Figure 4). In these metapelites, monazite occurs as small grain that rarely exceeds $50 \mu \mathrm{m}$.

The Sample RM 98-45 contains the assemblage Qtz + Pl + Bt + Ms \pm Grt with monazite and zircon as accessory phases. The lack of aluminosilicate minerals, such as kyanite and staurolite, is controlled by the bulk rock composition (chemical control), rather than by lower $P$ - $T$ conditions. All the monazite grains analyzed in this sample were located in the mineral matrix. The Samples RM99-58 and RM99-59 exhibit mineral assemblages of $\mathrm{Qtz}+\mathrm{Pl}+\mathrm{Bt}+\mathrm{Ms}+\mathrm{St}+\mathrm{Ky}$ with monazite and zircon as accessory minerals. In these samples, the geochronological data were obtained on monazite grains disseminated in the matrix but also from monazite included in staurolite. Some grains in the mineral matrix were included in cordierite surrounding staurolite suggesting that they were initially included in staurolite. The geochronological results for each of these three samples yield similar ${ }^{238} \mathrm{U} /{ }^{206} \mathrm{~Pb}$ lower intercept ages ranging between $41.26 \pm 0.36 \mathrm{Ma}(2 \sigma)$ and 


\section{RM 9845}
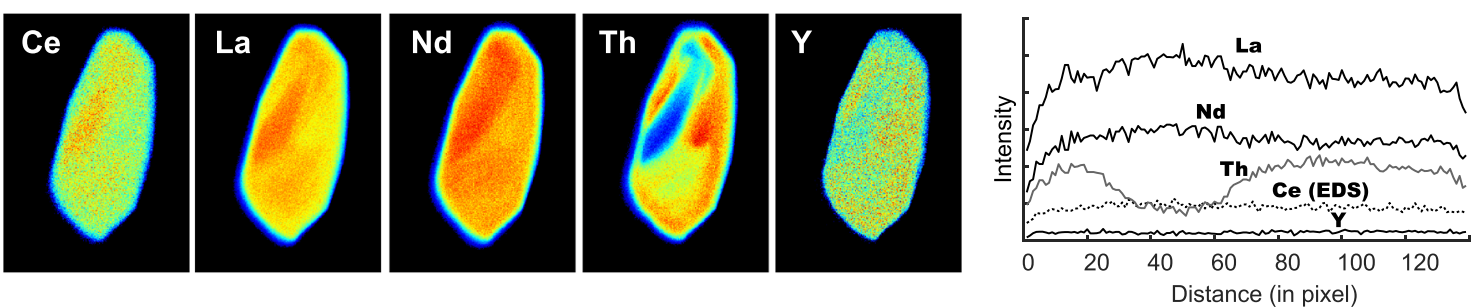

RM 9869
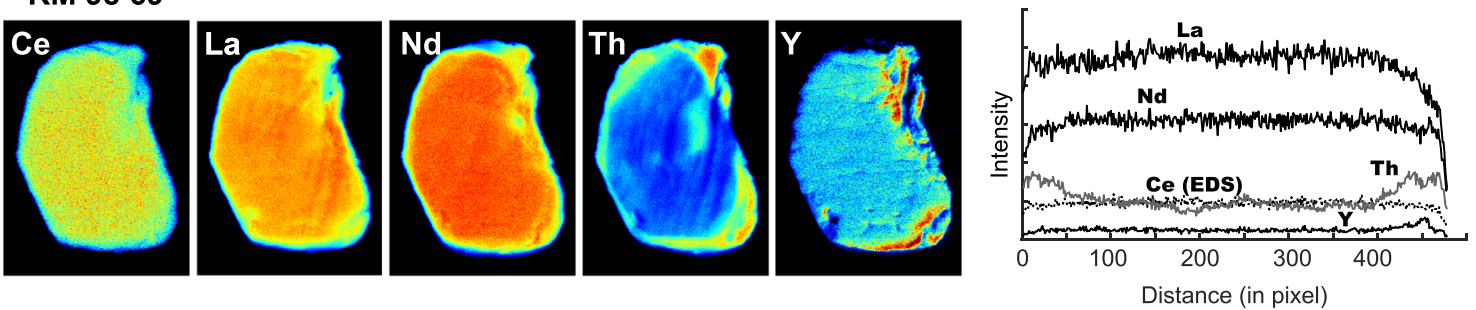

\section{RM 9877}
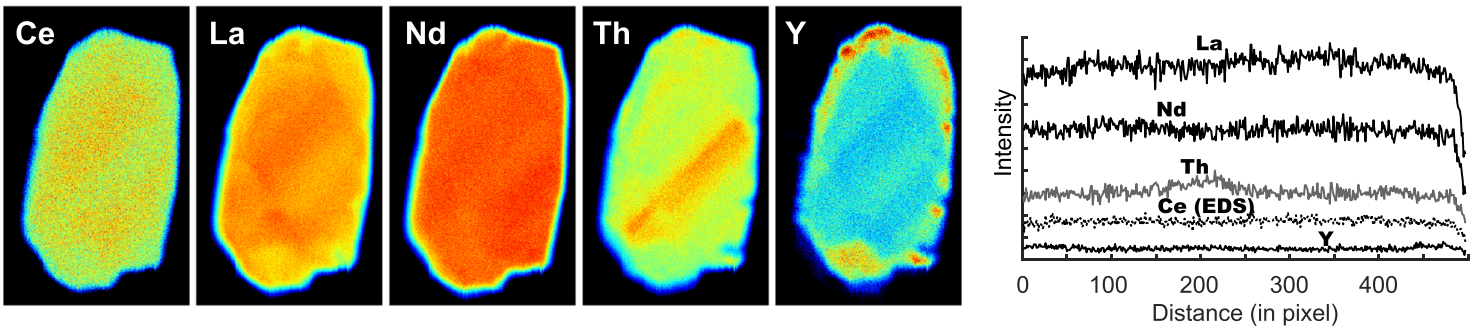

RM 9866
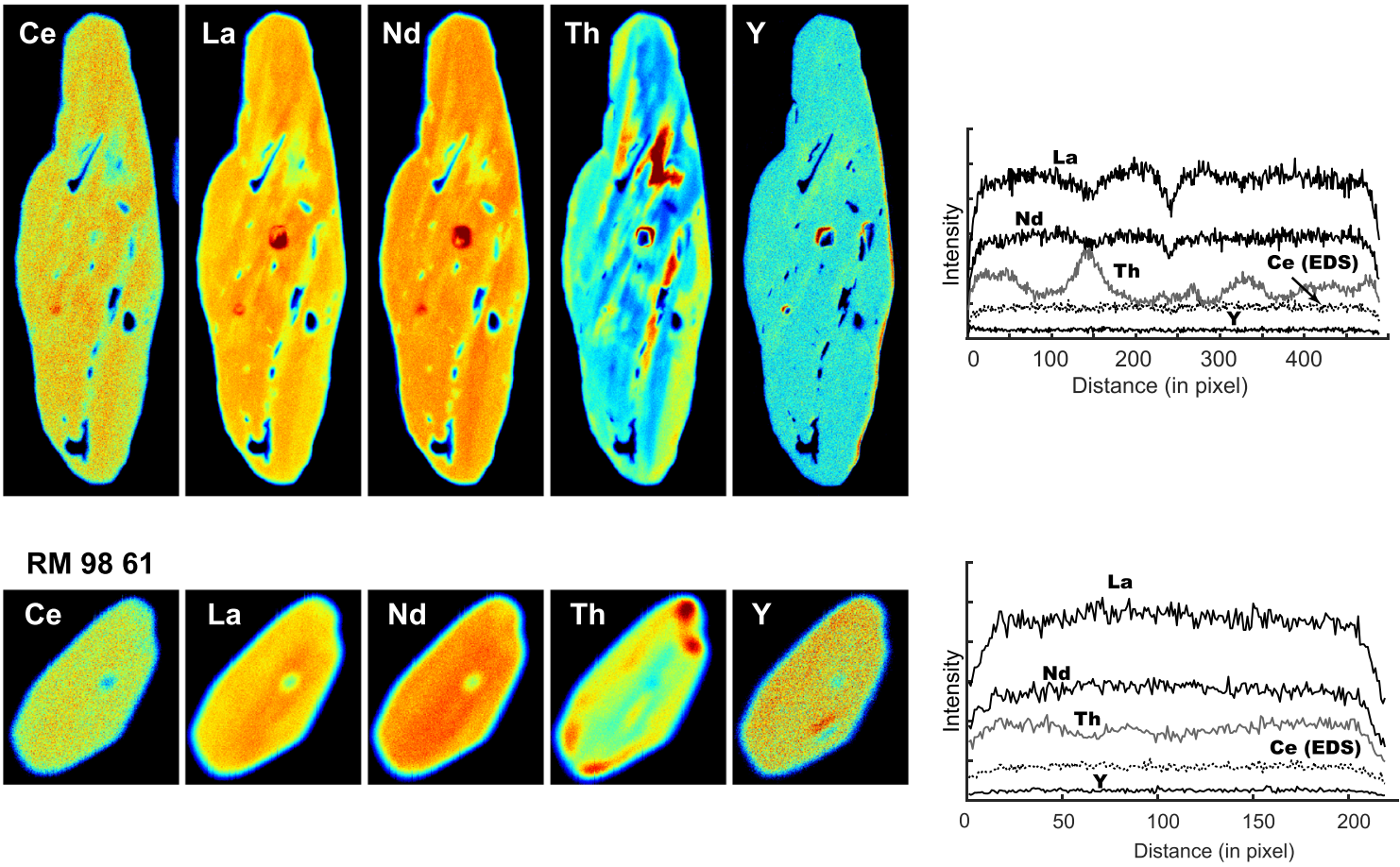

Figure 10. X-ray elemental maps of representative monazite crystals from the different sampling zones illustrating the zonation in Ce, La, Nd, Y, and Th. Warmer colors indicate higher concentration levels. The same color scale is applied for each element. Diagrams on the right side of the figure show the intensity profile of the REEs through the crystals. Except for Th, the intensity profiles reveal a homogeneous concentration in REE across the crystals. 

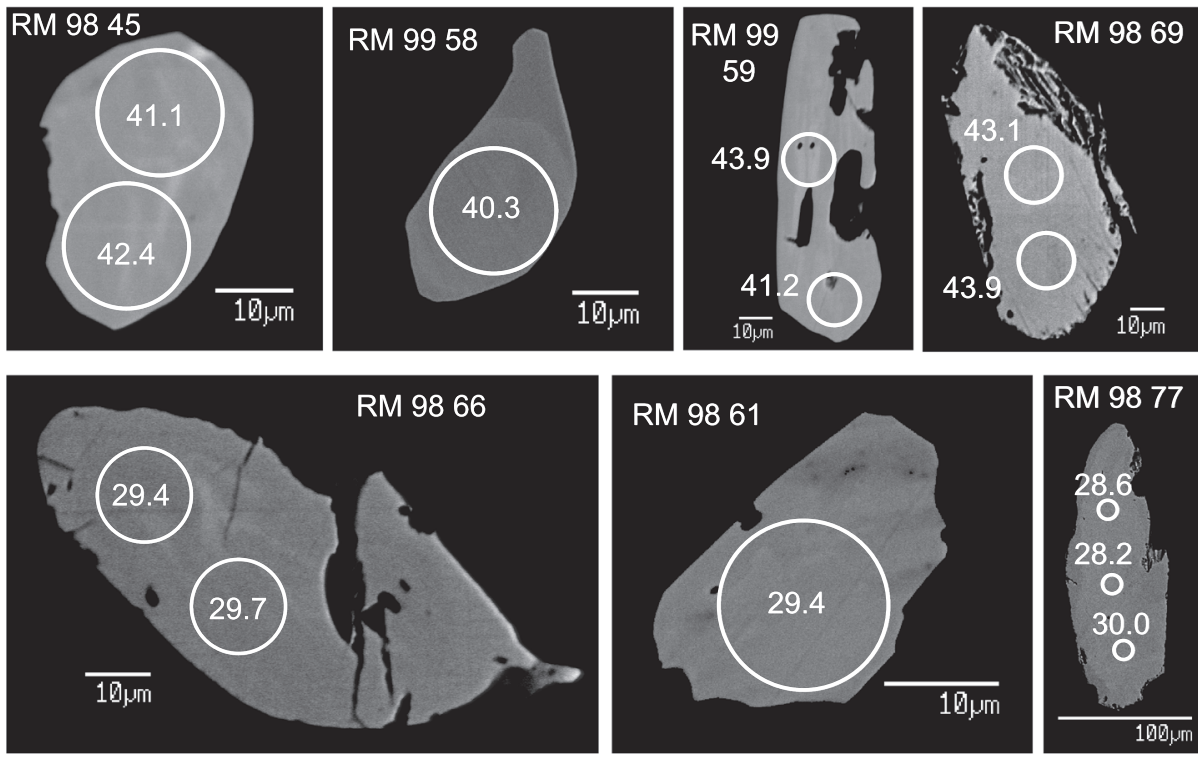

Figure 11. Backscattered electron images of selected monazites that are representative of each structural zone through the MSZ. Circles indicate the location of the spot analyses. Ages presented here are ${ }^{206} \mathrm{~Pb} /{ }^{238} \mathrm{U}$ ages in Ma.

$40.10 \pm 0.3 \mathrm{Ma}$. The observed similarities between ages for matrix monazite and inclusion monazite testify that the U-Th-Pb isotopic system was not reset after crystallization of monazite crystals. Likewise, the similarity in ages across each grain independently of the analysis location (core-rim, e.g., Samples RM 98-45 and RM 98-59 in Figure 11) attests that monazite crystallization occurred during a single metamorphic event within the uncertainty of the dating method.

The Sample RM 99-58 contains two monazite grains showing younger dates ( $28 \mathrm{Ma}$; see Figure 12c). As these two grains do not show any texture that could be linked to overgrowth or retrograde reactions, they are most likely younger monazite that crystallized during a late metamorphic stage. This age interpretation is supported by the observation that, compared to the Middle Eocene monazite in the mineral matrix, these two grains are enclosed in a quartz vein (Figure 13).

\subsection{Middle Part of the MTZ}

Structurally deeper in the shear zone, the Samples RM 98-66 and RM 98-69 have been selected for U-Th-Pb geochronology (Locality C; Figure 4). The outcrop locations of these samples are a few hundred meters apart. Sample RM 98-69 contains the mineral assemblage $\mathrm{Qtz}+\mathrm{Pl}+\mathrm{Bt}+\mathrm{Ms}+\mathrm{Ky}$ with monazite and zircon as accessory phases. The monazite grains selected for geochronology come from the mineral matrix except one grain that was partly included in kyanite. The Sample RM 98-69 yielded a lower intercept age of $42.89 \pm 0.36 \mathrm{Ma}(2 \sigma)$, in good agreement with ages obtained for the monazite of the upper part of the MTZ (Figure 12).

The second sample (RM 98-66) from the middle part of the MTZ contains the mineral assemblage $\mathrm{Qtz}+\mathrm{Pl}+\mathrm{Bt}+\mathrm{Ms}+\mathrm{St}+\mathrm{Ky}$ with monazite and zircon as accessory phases. In this sample, allanite is also present as inclusion in staurolite porphyroblasts. The growth of cordierite as postkinematic porphyroblast surrounding staurolite and kyanite grains testifies the nearly isothermal decompression experienced by this sample. The analyzed monazites from this sample are grains from the mineral matrix and grains included in cordierite and staurolite. The geochronological results yielded by the monazites from the Sample RM 98-66 are significantly younger with a lower intercept age of $28.39 \pm 0.24 \mathrm{Ma}(2 \sigma)$. The dates obtained for grains in the mineral matrix are overlapping with dates obtained from grains included in cordierite or staurolite. The similarity between monazite dates from the matrix and from monazites shielded in staurolite indicates that retrogression has not affected the U-Th-Pb system in this sample. The age difference between the two samples from the middle part of the MTZ can thus not be explained by partial resetting of the radiogenic system during decompression. 

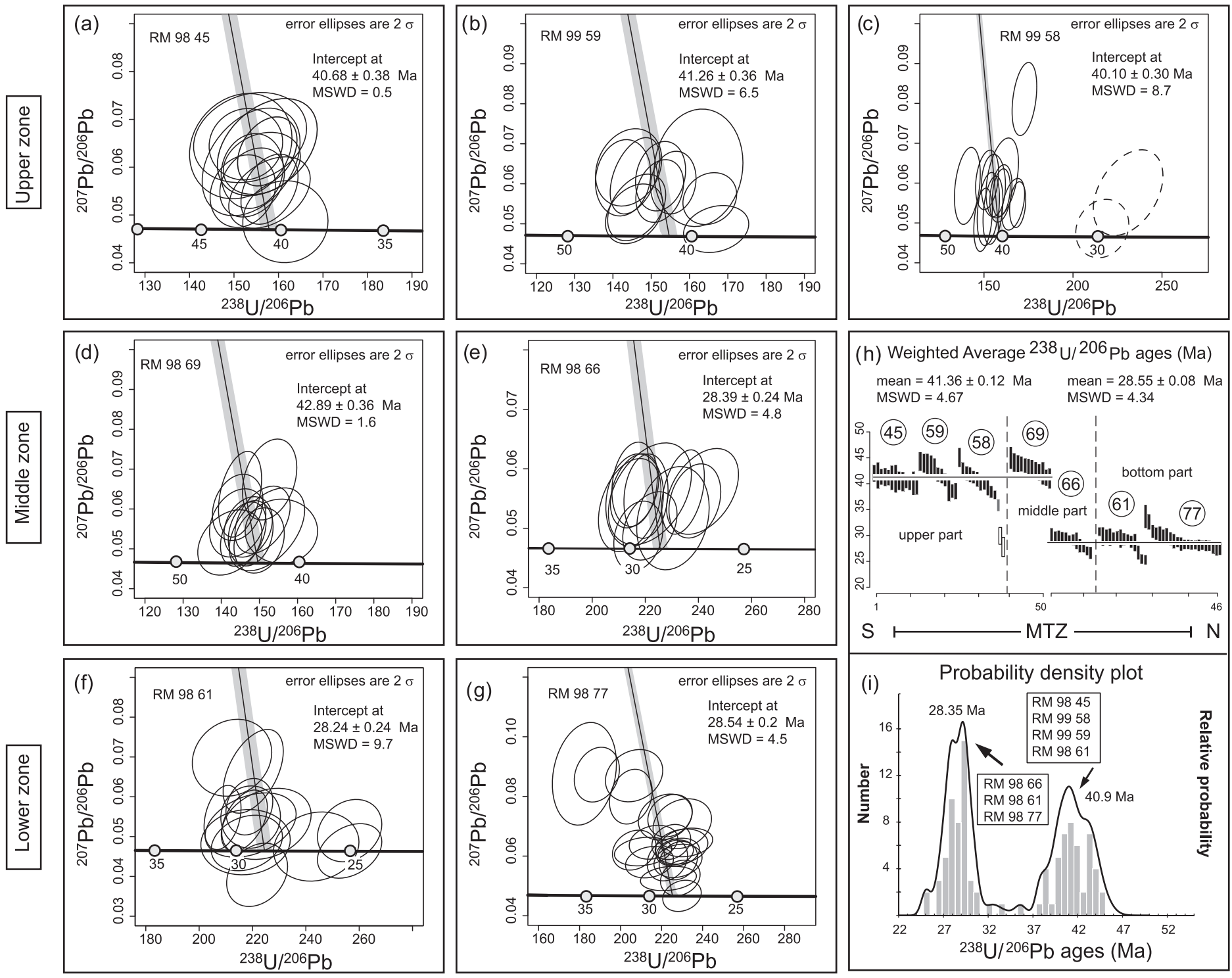

Figure 12. (a-g) Tera-Wasserburg plots for monazite from the different zones across the Miyar Shear Zone. A lower intercept age was obtained for each sample using an anchored isochron and a model value for the initial ${ }^{206} \mathrm{~Pb}$ composition (Stacey \& Kramers, 1975). This assumption has a minor effect as the monazite analyses very low amount of initial ${ }^{206} \mathrm{~Pb}$ (corresponding to $\mathrm{f}_{206}$ values of less than $3-5 \%$ ). (h) Weighted average Th-Pb age for all the samples across the Miyar Shear Zone. The individual dates were corrected for common lead using a 207-Pb correction (Burn et al., 2017). (i) Probability density plot generated using all common-lead corrected U-Pb dates of monazite across the Miyar Shear Zone.

\subsection{Bottom Part of the MTZ}

Two samples were selected in the deepest structural zone of the MTZ for U-Th-Pb geochronology. The Sample RM 98-61 contains the mineral assemblage Qtz + Pl + Bt + Ms. Aluminosilicate minerals are absent from this sample. Here monazite, which comes out as small grain of about 20-30 microns, does not show any significant zoning in BSE images. The lower intercept age for this sample is $28.24 \pm 0.24 \mathrm{Ma}(2 \sigma)$; a few younger dates are clustered at ca. $25 \mathrm{Ma}$ (Figure 12).

The sample RM 98-77 is the structurally deepest samples and is located at the boundary between the kyanite and sillimanite zones. It consists of a garnet-bearing schist. Garnet porphyroblasts in this sample commonly contain inclusions of both allanite and monazite, whereas only monazite is observed in the matrix assemblage. Monazite dates from this sample yield an age of 28.54 $\pm 0.20 \mathrm{Ma}$ (Figure 12). 


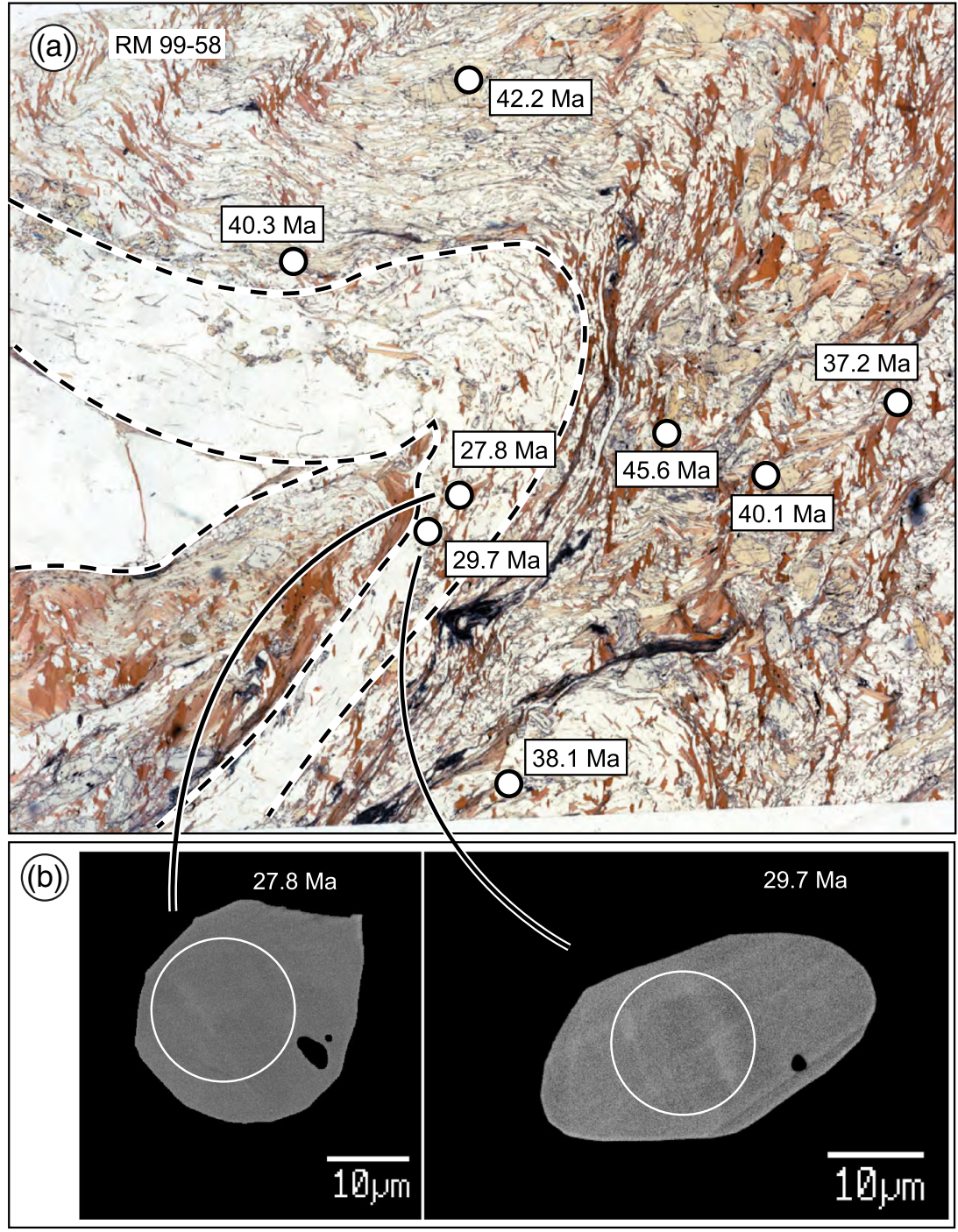

Figure 13. (a) Photomicrographs of thin section of the Sample RM 99-58 showing the location of the dated monazite grain through the section and illustrating the specific location in a quartz vein for the younger monazites. Ages are ${ }^{206} \mathrm{~Pb} /{ }^{238} \mathrm{U}$ ages. (b) BSE images of the two monazite grains that yield younger ages.

\section{Interpretation and Tectonic Implications}

The kinematic indicators demonstrate that both top-to-the-NE and top-to-the-SW contractional and extensional movements operated successively along the MSZ (Figure 3) (Horton et al., 2015; Robyr et al., 2002, 2006, 2014). In addition, microstructural investigations indicate that the earliest movements were associated with NE-directed shearing and occurred contemporaneously with the growth of snowball garnet in the hanging wall of the MTZ. This implies that the NE-verging structures are linked to a crustal thickening phase that took place in an early stage of the Himalayan tectonic history and that the overburden generated by this crustal thickening phase must have been significant enough to produce a medium $P$ - $T$ metamorphism in the Precambrian to Cambrian sediments of the Miyar Valley. Consequently, the early development of these NE structures combined with their association and Barrovian metamorphism refutes the model of NE-verging structures associated to local heterogeneities in strain during the main SW verging folding phase. Likewise, the Eocene monazite reported in our study are not compatible with models linking the NE-directed structures with a late backfolding phase. Regarding the tectonic wedge model (Webb et al., 2007; Yin, 2006), it has been shown in two studies focused on the Gianbul dome that this model was not suitable for explaining the early NE-directed movements observed along the Miyar valley (Horton et al., 2015; Robyr et al., 2014). 


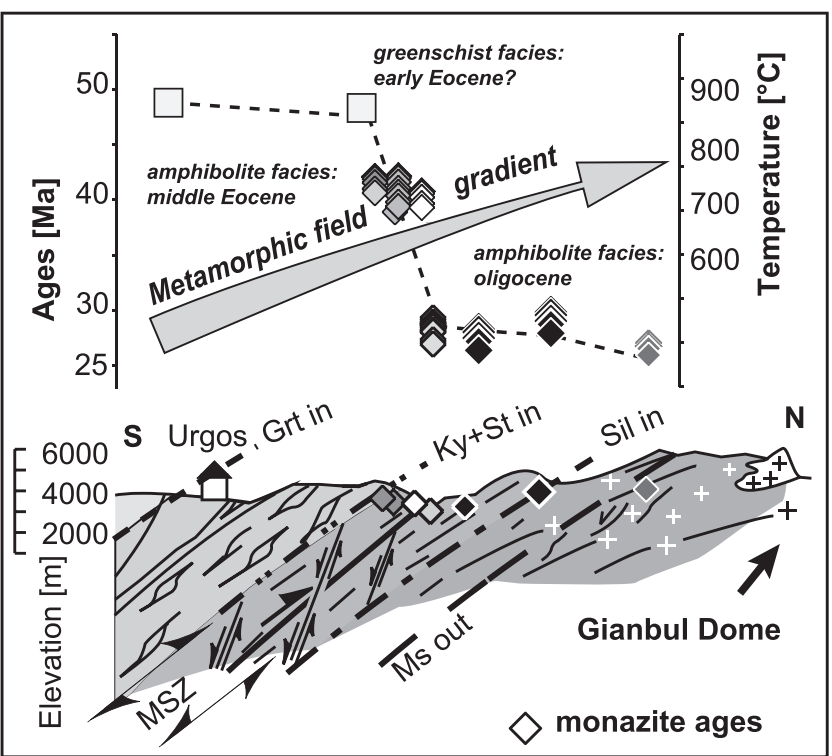

Figure 14. Monazite age distribution along the Miyar valley, based on the results presented in Figure 12. The northernmost sample has been dated by Robyr et al. (2006). The gray arrow represents the metamorphic field gradient for the Miyar valley in accordance with the $P$ - $T$ data presented in Robyr et al. (2002). MTZ = Miyar Thrust Zone.
The tectonic wedge model (Webb et al., 2007; Yin, 2006) postulates that the MTZ and the ZSZ consist of a single tectonic structure that developed on top of the HHC during its emplacement as a tectonic wedge. According to these authors, this model explains the alternating shear senses observed along the STDS (the MTZ-ZSZ branch in the case of this study) expressed by a shift from top-to-the-south to top-to-the-north shearing (Dèzes et al., 1999; Patel et al., 1993). Consequently, if the ZSZ and the MTZ were two segments of the same large structure, namely, the STDS, then both segments should record an identical kinematic history prior to the development of the Gianbul dome. Yet, the result provided in our study point to a contrasting and diachronic kinematic evolution between the MTZ and ZSZ. Indeed, along the MTZ, the first tectonic movements (D1) are associated with a NE-directed crustal thickening phase that is also linked to early Barrovian metamorphism (Stage M1) in the pelitic sediments of the Miyar Valley, whereas peak Barrovian metamorphism (Stage M2) occurred during an intertectonic phase at ca. $41 \mathrm{Ma}$ (Figure 12). By contrast, along the ZSZ, the first tectonic phase is related to top-to-the-south contractional movements collectively correlated to the northward underthrusting of the HHC below the frontal part of the Tethyan Himalaya. This tectonic phase is also responsible for the Barrovian metamorphism that developed between ca. 35 and $30 \mathrm{Ma}$ along the ZSZ (M1 of the ZSZ) (Vance \& Harris, 1999; Walker et al., 1999). Across the ZSZ, the SW-directed contractional structures are overprinted by NE-directed extensional structures developed during the reactivation of the ZSZ as a ductile zone of extension during early Miocene (22.2-19.8 Ma) (Dèzes et al., 1999). These data reveal a gap of more than $25 \mathrm{Myr}$ between the development of the NE-directed structures along the MTZ and the ZSZ attesting that both, the MTZ and the ZSZ, did not experience the same kinematic history. In addition, geochronological data demonstrate that the movements along the MSZ ceased at ca. 23 Ma (Robyr et al., 2014) while the main ductile shearing along the ZSZ occurred between 22.2 and 19.8 Ma (Dèzes et al., 1999) testifying that the displacements along the MTZ and the ZSZ were not synchronously active. Consequently, the predictions of the tectonic wedge model involving parallel kinematic histories for both, the MTZ and the ZSZ, are attested neither by our field observations nor by the existing geochronological data. Thus, the tectonic wedge model does not provide a satisfactory explanation for the kinematic evolution of the MTZ that is characterized by the onset of NE-directed movements in an early stage of its kinematic history (Horton et al., 2015; Robyr et al., 2014).

Monazite grains included in garnet or staurolite yield the same age than monazite grains located in the matrix. This feature attests that a single population of monazite is present and that the U-Th- $\mathrm{Pb}$ isotopic system did not experience resetting during subsequent geologic events and confirms thus that monazite ages presented in this study are interpreted as crystallization ages. The geochronological data set indicates that at the top of the MTZ, the HHCZ rocks reached the temperature of allanite/monazite transition $\left(600^{\circ} \mathrm{C}\right.$ isotherm) about $41 \mathrm{Myr}$ ago, while the rocks in the structurally deeper parts of the shear zone reached equivalent temperatures $12 \mathrm{Myr}$ later, at ca. $28 \mathrm{Ma}$. These results are in line with the microstructural observations, which revealed a distinct tectono-metamorphic record between the samples located at the top and the bottom of the MTZ.

Two key pieces of information can be derived from these results: (1) The Barrovian metamorphism recorded in metapelites of the Miyar valley occurred in two successive stages, an Eocene phase and an Oligocene phase, and (2) monazite ages decrease northward as the metamorphic conditions increase (Figure 14).

According to the classical kinematic model for the HHC, the metamorphic imprint in this unit results from the NE underthrusting of the HHC high-grade rocks below the Tethyan Himalaya (Dèzes, 1999; Vannay et al., 2004; Vannay \& Grasemann, 2001; Wiesmayr \& Grasemann, 2002). If this classical view of the kinematic evolution of the HHC was pertinent to the HHCZ of the Miyar valley, one would expect rocks located at the leading edge of the subducting slab to be metamorphosed first. Rocks with the highest metamorphic grade should thus have recorded the oldest (monazite) ages in the slab. The geochronological data from the 
SW

NE
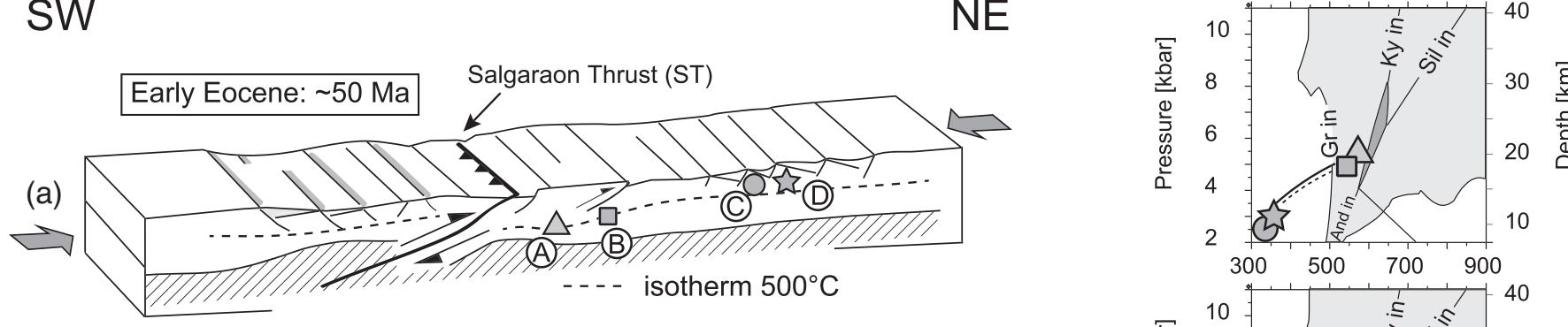

Middle Eocene : 40Ma

ST $\quad$ MT1

(b)
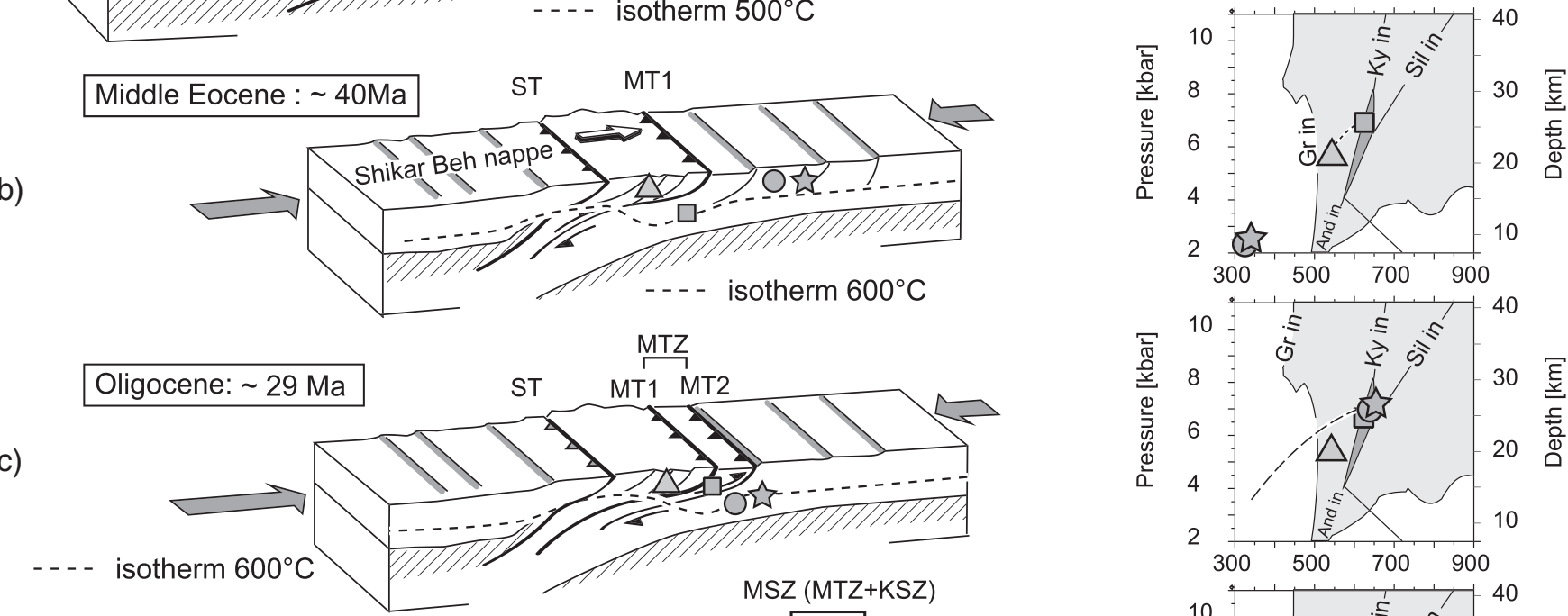

MTZ
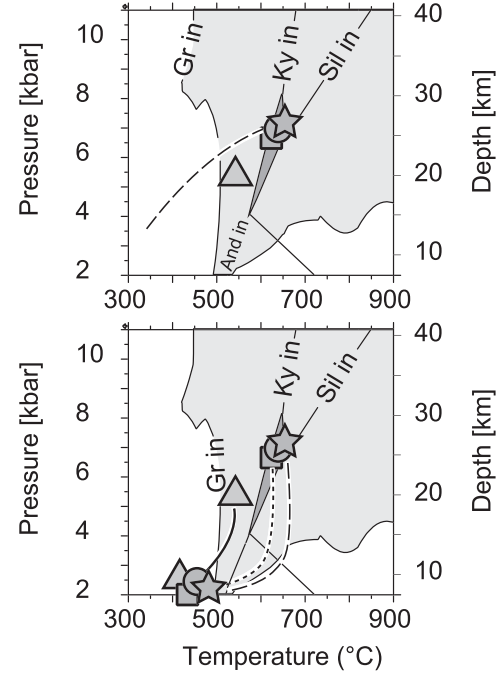

(d)

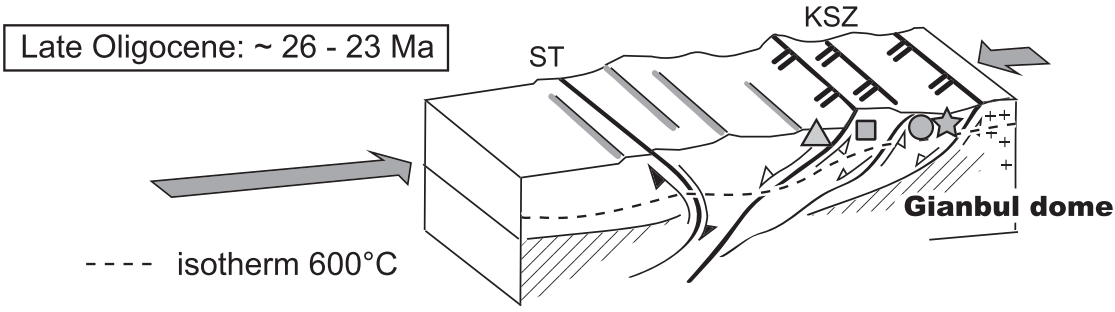

Temperature $\left({ }^{\circ} \mathrm{C}\right)$

Figure 15. Eocene to Miocene kinematic evolution of the MSZ on the southern limb of the Gianbul dome. This reconstruction is based on the structural and geochronological constraints presented in the present study, as well as on the data from Robyr et al. (2002). The triangle, square, and circle symbols correspond to representative samples (or groups of samples) constraining the underthrusting depth, peak temperature, and chronology of crystallization of monazite in the various zones exposed along the section. (a)-(d) referred to the samples from the hanging wall, the upper part, middle part, and bottom part of the Miyar Shear Zone respectively. The diagrams on the right correspond to $P$ - $T$ diagram showing the metamorphic evolution of each representative samples. $P$ - $T$ estimates for the samples of the different structural zone are from Robyr et al. (2002) and Goswami-Banerjee and Robyr (2015).

Miyar valley clearly differ from these predictions. Instead, the age distribution of metamorphic monazite along the Miyar valley are in line with a scenario of southward underthrusting of the HHCZ along the MTZ, below the Shikar Beh nappe. The geochronological data, together with the $P$ - $T$ and microstructural analyses, enable the construction of a model for the kinematic evolution of the MSZ prior exhumation (Figure 15).

This model implies that the HHCZ in the Miyar valley consists of several tectonic slices that were successively southwestward underthrust as a consequence of NE-directed propagation of crustal deformation associated with the Shikar Beh nappe emplacement (Figure 15). An early phase of NE-directed tectonism affected the sedimentary sequence deposited on the Indian margin (Figure 15a). Crustal shortening associated with this tectonic phase was mainly accommodated by thrusting along the Salgaraon Thrust (Steck et al., 1999) in the Chenab valley southwest of Udaipur and by large-scale NE-verging folding in the southern part of the Miyar valley. During this stage, the rocks situated nowadays in the hanging wall (Sample A) and the upper part of the MTZ (Sample B) were metamorphosed under $P$ - $T$ conditions prevailing for chlorite to garnet crystallization (Figure 15a). As this event largely predates the crystallization of staurolite (40 Ma) in the middle Eocene in Sample B, this first tectono-metamorphic episode must have 
occurred in the early Eocene, slightly after the India-Asia continental collision. From the middle Eocene, a discrete thrust structure, that is, the Miyar Thrust (MT1), developed at the advancing front of this NE-directed folding phase, leading to the formation of the Shikar Beh nappe (Figure 15b). During this stage, the metapelites of the Miyar valley, in the footwall of the Miyar Thrust (Sample B; RM 98-56 and RM 98-59), were buried to $25 \mathrm{~km}$ depth where metamorphic monazite grew at $\sim 600^{\circ} \mathrm{C}$, and staurolite-bearing assemblages formed in metapelites (Robyr et al., 2002). From this time on, the dynamics of the system weakened, probably because most of the shortening was since then accommodated by northward underthrusting of the HHCZ below the frontal part of the north Himalayan nappes between 33 and 28 Ma (e.g., Vance \& Harris, 1999). Beneath the Zanskar thrust, the rocks were subducted down to $\sim 30 \mathrm{~km}$ depth, where temperatures up to $750-850^{\circ} \mathrm{C}$ triggered partial melting (Dèzes et al., 1999). During the early Oligocene, 28 Myr ago, the NE-directed thrust system at the front of the Shikar Beh nappe was reactivated as a ductile shear zone (MTZ) and rapid burial along the MTZ transforming the HHCZ rocks of the upstream part of the Miyar section into amphibolite facies to migmatitic paragneiss (Figure 15c). During the late Oligocene (between 26.6 and $23 \mathrm{Ma}$; Robyr et al., 2006), the onset of the exhumation of the Gianbul dome triggers the reactivation of the MTZ as a ductile zone of extension referred to as the KSZ (Robyr et al., 2002; Steck et al., 1999). Simultaneously, the exhumation of the HHCZ as a dome structure was accompanied by extension along the ZSZ that reactivated the frontal thrust of the North Himalayan nappes (Patel et al., 1993). The rapid exhumation of the HHC high-grade rocks caused a nearly isothermal decompression resulting in partial migmatization of the paragneiss forming now the core of the Gianbul dome. Following an initial doming phase that ended by $22 \mathrm{Ma}$ with the cessation of the movements along the MTZ (Robyr et al., 2006, 2014), further coeval extension along the ZSZ and thrusting along the MCT lead to the tectonically extrusion of the HHC toward the south.

\section{Conclusions}

Along the Miyar valley, the spatial-temporal distribution of U-Th-Pb monazite ages shows a northward decrease, that is, into deeper structural levels. This distribution is interpreted to reflect a metamorphic evolution of the HHCZ in the Upper Lahul region that is related to a phase of crustal thickening by the northward propagation of NE-directed deformation. These results testify that the numerous structures showing a top-to-the-NE sense of shear observed in Upper Lahul cannot be interpreted as local heterogeneities in deformation during the predominant SW-directed folding and thrusting. Rather, these data support that an early Eocene deformation manifested by folding and thrusting toward the NE. The resulting Shikar Beh nappe is consequently the oldest Tertiary intracontinental nappe structure of the north Indian crust that was accreted in the Himalayan range. This early Eocene tectonic phase was strong enough to induce medium pressure regional metamorphism up to partial melting grade in the Upper Lahul region (Epard et al., 1995; Robyr et al., 2002). The overburden to $\sim 25 \mathrm{~km}$ associated with the NE-directed development of this crustal thickening phase may have prevented the extrusion of the high-grade metamorphic rocks of the HHC in the frontal part of the range along the MCT such as observed in most Himalayan sections (Robyr et al., 2006, 2014). By contrast, the presence of a major shear zone (MTZ) in the frontal part of the Shikar Beh nappe induced a weakness in the upper crust that facilitated the exhumation of the high-grade rocks of the HHCZ of Zanskar as a large-scale dome structure in a more internal part of the range.

The Shikar Beh nappe thus appears to have played a major role in the kinematic evolution of this portion of the Himalaya, and its emplacement constitutes a critical phase in the early history of the Himalayan orogen. The results of this study clearly identify that early Eocene NE-directed crustal thickening and thrusting are responsible for the contrasting geological structures and metamorphic zonation observed in the northwestern part of the Himalaya of India. In a broader sense, these results reveal that crustal shortening during the initial stage of continental subduction is not exclusively accommodated by foreland-directed folding and thrusting but may also be adapted by deformation involving opposite-directed vergence.

\section{Data Availability Statement}

The instrumental setup and operating conditions to determine the U-Th- $\mathrm{Pb}$ ages of monazite and the complete data set of the U-Th-Pb ages are available in the supporting information. Full data set is available in the http://zenodo.org repository at http://doi.org/10.5281/zenodo.4247956. 


\section{Acknowledgments}

Two anonymous reviewer made helpful suggestions that improved the clarity of the manuscript. We thank the associate editor for providing a constructive review of the manuscript. This work was supported by the Swiss National Science Foundation (FNRS grant 200021_135335).

\section{References}

Burchfiel, B. C., Chen, Z., Hodges, K. V., Liu, Y., Royden, L. H., Deng, C., \& Xu, J. (1992). The South Tibetan Detachment System, Himalayan Orogen: Extension contemporaneous with and parallel to shortening in a collisional mountain belt. The Geological Society of America Special Paper, 269, 1-41. https://doi.org/10.1130/SPE269-p1

Burg, J. P., \& Chen, G. M. (1984). Tectonics and structural zonation of southern Tibet, China. Nature, 311(5983), 219-223. https://doi.org/ $10.1038 / 311219 \mathrm{a} 0$

Burn, M., Lanari, P., Pettke, T., \& Engi, M. (2017). Non-matrix-matched standardisation in LA-ICP-MS analysis: General approach, and application to allanite Th-U-Pb dating. Journal of Analytical Atomic Spectrometry, 32, 1359-1377. https://doi.org/10.1039/C7JA00095B

Caby, R., Pecher, A., \& Lefort, P. (1983). The Himalayan Central Thrust-New data about the reverse metamorphism at the bottom of the Tibetan slab. Revue De Geologie Dynamique Et De Geographie Physique, 24, 89-100.

Carosi, R., Montomoli, C., \& Iaccarino, S. (2018). 20 years of geological mapping of the metamorphic core across Central and Eastern Himalayas. Earth-Science Reviews, 177, 124-138. https://doi.org/10.1016/j.earscirev.2017.11.006

Carosi, R., Montomoli, C., Iaccarino, S., Massonne, H.-J., Rubatto, D., Langone, A., et al. (2016). Middle to late Eocene exhumation of the Greater Himalayan Sequence in the Central Himalayas: Progressive accretion from the Indian plate. GSA Bulletin, 128, $1571-1592$. https://doi.org/10.1130/B31471.1

Carosi, R., Montomoli, C., Rubatto, D., \& Visona, D. (2013). Leucogranite intruding the South Tibetan Detachment in western Nepal; implications for exhumation models in the Himalayas. Terra Nova, 25, 478-489. https://doi.org/10.1111/ter.12062

Cherniak, D. J., Watson, E. B., Grove, M., \& Harrison, T. M. (2004). Pb diffusion in monazite: A combined RBS/SIMS study. Geochimica et Cosmochimica Acta, 68(4), 829-840. https://doi.org/10.1016/j.gca.2003.07.012

Coleman, M. E. (1998). U-PB constraints on oligocene-miocene deformation and anatexis within the central Himalaya, Marsyandi valley, Nepal. American Journal of Science, 298(7), 553-571. https://doi.org/10.2475/ajs.298.7.553

de Sigoyer, J., Chavagnac, V., Blichert-Toft, J., Villa, I. M., Luais, B., Guillot, S., et al. (2000). Dating the Indian continental subduction and collisional thickening in the northwest Himalaya: Multichronology of the Tso Morari eclogites. Geology, 28(6), 487-490. https://doi.org/ 10.1130/0091-7613(2000)28<487:DTICSA >2.0.CO;2

Dèzes, P. (1999). Tectonic and metamorphic evolution of the Central Himalayan Domain in Southeast Zanskar (Kashmir, India) (p. 133). Mémoire de Géologie (Lausanne).

Dèzes, P. J., Vannay, J. C., Steck, A., Bussy, F., \& Cosca, M. (1999). Synorogenic extension: Quantitative constraints on the age and displacement of the Zanskar shear zone (northwest Himalaya). Geological Society of America Bulletin, 111(3), 364-374. https://doi.org/ 10.1130/0016-7606(1999)111<0364:SEQCOT>2.3.CO;2

Epard, J. L., \& Steck, A. (2004). The eastern prolongation of the Zanskar Shear Zone (Western Himalaya). Eclogae Geologicae Helvetiae, 97(2), 193-212. https://doi.org/10.1007/s00015-004-1116-7

Epard, J. L., Steck, A., Vannay, J. C., \& Hunziker, J. (1995). Tertiary Himalayan structures and metamorphism in the Kulu valley (Mandi-Khoksar transect of the western Himalaya)—Shikar Beh Nappe and Crystalline Nappe. Schweizerische Mineralogische und Petrographische Mitteilungen, 75, 59-84.

Frank, W., Baud, A., Honegger, K., \& Trommsdorff, V. (1987). Comparative studies on profiles across the Northwest Himalayas. In J.-P. Schaer \& J. Rodgers (Eds.), The anatomy of mountain ranges (pp. 261-275). Princeton, NJ: Princeton University Press.

Frank, W., Thoni, M., \& Purtscheller, F. (1977). Geology and petrography of Kulu-South Lahul area. Colloques Internationaux du Centre National de la Recherche Scientifique, 268, 147-172.

Fuchs, G., \& Linner, M. (1995). Geological traverse across the Western Himalaya-A contribution to the geology of eastern Ladakh, Lahul, and Chamba. Jahrbuch der Geologischen Bundesanstalt, 138, 55-685.

Gansser, A. (1964). In Geology of the Himalayas (pp. 1-289). London: Wiley.

Garzanti, E., Baud, A., \& Mascle, G. (1987). Sedimentary record of the northward flight of India and its collision with Eurasia (Ladakh Himalaya, India). Geodinamica Acta, 1(4-5), 297-312. https://doi.org/10.1080/09853111.1987.11105147

Godin, L., Grujic, D., Law, R. D., \& Searle, M. P. (2006). Channel flow, ductile extrusion and exhumation in continental collision zones: An introduction. In R. D. Law, M. P. Searle, L. Godin (Eds.), Channel flow, ductile extrusion and exhumation in continental collision zones Channel flow, ductile extrusion and exhumation in continental collision zones, Geological Society Special Publication (Vol. 268, pp. 1-23). Bath, UK: The Geological Society Publishing House.

Goswami-Banerjee, S., \& Robyr, M. (2015). Pressure and temperature conditions for crystallization of metamorphic allanite and monazite in metapelites: A case study from the Miyar Valley (High Himalayan Crystalline of Zanskar, NW India). Journal of Metamorphic Geology, 33, 535-556. https://doi.org/10.1111/jmg.12133

Gregory, C. J., Rubatto, D., Hermann, J., Berger, A., \& Engi, M. (2012). Allanite behaviour during incipient melting in the southern Central Alps. Geochimica et Cosmochimica Acta, 84, 433-458. https://doi.org/10.1016/j.gca.2012.01.020

Harrison, T. M., Catlos, E. J., \& Montel, J. M. (2002). U-Th-Pb dating of phosphate minerals. In M. J. Kohn, J. Rakovan, J. M. Hughes (Eds.), Phosphates: Geochemical, geobiological, and materials importance (Vol. 48, pp. 523-558). Chantilly: Mineralogical Society of America and Geochemical Society.

Herren, E. (1987). Zanskar shear zone-northeast-southwest extension within the higher Himalayas (Ladakh, India). Geology, 15(5), 409-413. https://doi.org/10.1130/0091-7613(1987)15<409:ZSZNEW>2.0.CO;2

Hodges, K. V., Parrish, R. R., Housh, T. B., Lux, D. R., Burchfiel, B. C., Royden, L. H., \& Chen, Z. (1992). Simultaneous Miocene extension and shortening in the Himalayan Orogen. Science, 258(5087), 1466-1470. https://doi.org/10.1126/science.258.5087.1466

Hodges, K. V., Parrish, R. R., \& Searle, M. P. (1996). Tectonic evolution of the central Annapurna Range, Nepalese Himalayas. Tectonics, 15(6), 1264-1291. https://doi.org/10.1029/96TC01791

Horstwood, M. S. A., Foster, G. L., Parrish, R. R., Noble, S. R., \& Nowell, G. M. (2003). Common-Pb corrected in situ U-Pb accessory mineral geochronology by LA-MC-ICP-MS. Journal of Analytical Atomic Spectrometry, 18(8), 837-846. https://doi.org/10.1039/B304365G

Horton, F., Lee, J., Hacker, B., Bowman-Kamaha'o, M., \& Cosca, M. (2015). Himalayan gneiss dome formation in the middle crust and exhumation by normal faulting: New geochronology of Gianbul dome, northwestern India. Geological Society of America Bulletin, 127(1-2), 162-180. https://doi.org/10.1130/B31005.1

Hubbard, M. S., \& Harrison, T. M. (1989). Ar-40/Ar-39 age constraints on deformation and metamorphism in the Main Central Thrust Zone and Tibetan slab, eastern Nepal Himalaya. Tectonics, 8(4), 865-880. https://doi.org/10.1029/TC008i004p00865

Iaccarino, S., Montomoli, C., Carosi, R., Montemagni, C., Massonne, H. J., Langone, A., et al. (2017). Pressure-temperature-deformationtime constraints on the South Tibetan Detachment System in the Garhwal Himalaya (NW India). Tectonics, 36, 2281-2304. https://doi. org/10.1002/2017TC004566 
Janots, E., Engi, M., Berger, A., Allaz, J., Schwarz, J. O., \& Spandler, C. (2008). Prograde metamorphic sequence of REE minerals in pelitic rocks of the Central Alps: Implications for allanite-monazite-xenotime phase relations from 250 to 610 degrees C. Journal of Metamorphic Geology, 26(5), 509-526. https://doi.org/10.1111/j.1525-1314.2008.00774.x

Montemagni, C., Carosi, R., Fusi, N., Iaccarino, S., Montomoli, C., Villa, I. M., \& Zanchetta, S. (2020). Three-dimensional vorticity and time-constrained evolution of the Main Central Thrust zone, Garhwal Himalaya (NW India). Terra Nova, 32, 215-224. https://doi.org/ $10.1111 /$ ter. 12450

Parrish, R. R. (1990). U-Pb dating of monazite and its application to geological problems. Canadian Journal of Earth Sciences, 27(11), 1431-1450. https://doi.org/10.1139/e90-152

Patel, R. C., Singh, S., Asokan, A., Manickavasagam, R. M., \& Jain, A. K. (1993). Extensional tectonics in the Himalayan orogen, Zanskar, NW India. In P. J. Treloar, \& M. P. Searle (Eds.), Himalayan tectonics, Special Publications (Vol. 74, pp. 445-459). London: Geological Society.

Paton, C., Hellstrom, J., Paul, B., Woodhead, J., \& Hergt, J. (2011). Iolite: Freeware for the visualisation and processing of mass spectrometric data. Journal of Analytical Atomic Spectrometry, 26(12), 2508-2518. https://doi.org/10.1039/c1ja10172b

Patriat, P., \& Achache, J. (1984). India-Eurasia collision chronology has implications for crustal shortening and driving mechanism of plates. Nature, 311(5987), 615-621. https://doi.org/10.1038/311615a0

Petrus, J. A., \& Kamber, B. S. (2012). VizualAge: A novel approach to laser ablation ICP-MS U-Pb geochronology data reduction. Geostandards and Geoanalytical Research, 36(3), 247-270. https://doi.org/10.1111/j.1751-908X.2012.00158.x

Pognante, U., Castelli, D., Benna, P., Genovese, G., Oberli, F., Meier, M., \& Tonarini, S. (1990). The crystalline units of the high Himalayas in the Lahul-Zanskar region (Northwest India): Metamorphic-tectonic history and geochronology of the collided and imbricated Indian plate. Geological Magazine, 127(2), 101-116. https://doi.org/10.1017/S0016756800013807

Robyr, M. (2002). Thrusting, extension and doming in the High Himalaya of Lahul-Zanskar area (NW India) (p.126). Structural and pressure-temperature constraints, Mémoire de Géologie (Lausanne).

Robyr, M., Epard, J.-L., \& El Korh, A. (2014). Structural, metamorphic and geochronological relations between the Zanskar Shear Zone and the Miyar Shear Zone (NW Indian Himalaya): Evidence for two distinct tectonic structures and implications for the evolution of the High Himalayan Crystalline of Zanskar. Journal of Asian Earth Sciences, 79, 1-15. https://doi.org/10.1016/j. jseaes.2013.09.007

Robyr, M., Hacker, B. R., \& Mattinson, J. M. (2006). Doming in compressional orogenic settings: New geochronological constraints from the NW Himalaya. Tectonics, 25, TC2007. https://doi.org/10.1029/2004TC001774

Robyr, M., Vannay, J. C., Epard, J. L., \& Steck, A. (2002). Thrusting, extension, and doming during the polyphase tectonometamorphic evolution of the High Himalayan Crystalline Zone in NW India. Journal of Asian Earth Sciences, 21(3), 221-239. https://doi.org/10.1016/ S1367-9120(02)00039-1

Rowley, D. B. (1996). Age of initiation of collision between India and Asia: A review of stratigraphic data. Earth and Planetary Science Letters, 145(1-4), 1-13. https://doi.org/10.1016/S0012-821X(96)00201-4

Scherrer, N. C., Engi, M., Cheburkin, A., Parrish, R. R., \& Berger, A. (2002). Non-destructive chemical dating of young monazite using XRF: 2. Context sensitive microanalysis and comparison with Th-Pb laser-ablation mass spectrometric data (LA-PIMMS). Chemical Geology, 191, 241-253.

Schlup, M., Steck, A., Carter, A., Cosca, M., Epard, J. L., \& Hunziker, J. (2011). Exhumation history of the NW Indian Himalaya revealed by fission track and ${ }^{40} \mathrm{Ar} /{ }^{39} \mathrm{Ar}$ ages. Journal of Asian Earth Sciences, 40(1), 334-350. https://doi.org/10.1016/j.jseaes.2010.06.008

Searle, M. P., Law, R. D., Godin, L., Larson, K. P., Streule, M. J., Cottle, J. M., \& Jessup, M. J. (2008). Defining the Himalayan Main Central Thrust in Nepal. Journal of the Geological Society, 165(2), 523-534. https://doi.org/10.1144/0016-76492007-081

Singh, K. (2012). Opposite vergent synclines on the flanks of a large-scale box fold in the Chamba-Lahaul region, northwest Himalaya, India. International Journal of Earth Sciences, 101(4), 997-1008. https://doi.org/10.1007/s00531-011-0707-6

Smith, H. A., \& Giletti, B. J. (1997). Lead diffusion in monazite. Geochimica et Cosmochimica Acta, 61(5), 1047-1055. https://doi.org/ 10.1016/S0016-7037(96)00396-1

Stacey, J. S., \& Kramers, J. D. (1975). Approximation of terrestrial lead isotope evolution by a two-stage model. Earth and Planetary Science Letters, 26(2), 207-221. https://doi.org/10.1016/0012-821X(75)90088-6

Steck, A. (2003). Geology of the NW Indian Himalaya. Eclogae Geologicae Helvetiae, 96, 147-196.

Steck, A., Epard, J. L., \& Robyr, M. (1999). The NE-directed Shikar Beh Nappe: A major structure of the Higher Himalaya. Eclogae Geologicae Helvetiae, 92, 239-250.

Steck, A., Epard, J. L., Vannay, J. C., Hunziker, J., Girard, M., Morard, A., \& Robyr, M. (1998). Geological transect across the Tso Morari and Spiti areas: The nappe structures of the Tethys Himalaya. Eclogae Geologicae Helvetiae, 91, 103-122.

Steck, A., Spring, L., Vannay, J.-C., Masson, H., Bucher, H., Stutz, E., et al. (1993). The tectonic evolution of the Northwestern Himalaya in eastern Ladakh and Lahul, India. Geological Society, London, Special Publications, 74(1), 265-276. https://doi.org/10.1144/GSL. SP.1993.074.01.19

Steck, A., Spring, L., Vannay, J. C., Masson, H., Stutz, E., Bucher, H., et al. (1993). Geological transect across the northwestern Himalaya in eastern Ladakh and Lahul (a model for the continental collision of India and Asia). Eclogae Geologicae Helvetiae, 86, $219-263$.

Vance, D., \& Harris, N. (1999). Timing of prograde metamorphism in the Zanskar Himalaya. Geology, 27(5), 395-398. https://doi.org/ 10.1130/0091-7613(1999)027<0395:TOPMIT>2.3.CO;2

Vannay, J. C., \& Grasemann, B. (2001). Himalayan inverted metamorphism and syn-convergence extension as a consequence of a general shear extrusion. Geological Magazine, 138(3), 253-276. https://doi.org/10.1017/S0016756801005313

Vannay, J. C., Grasemann, B., Rahn, M., Frank, W., Carter, A., Baudraz, V., \& Cosca, M. (2004). Miocene to Holocene exhumation of metamorphic crustal wedges in the NW Himalaya: Evidence for tectonic extrusion coupled to fluvial erosion. Tectonics, 23 , TC1014. https://doi.org/10.1029/2002TC001429

Vannay, J. C., \& Steck, A. (1995). Tectonic evolution of the High Himalaya in Upper Lahul (NW Himalaya, India). Tectonics, 14(2), 253-263. https://doi.org/10.1029/94TC02455

Vermeesch, P. (2018). IsoplotR: A free and open toolbox for geochronology. Geoscience Frontiers, 9, 1479-1493. https://doi.org/10.1016/j. gsf.2018.04.001

Walker, J. D., Martin, M. W., Bowring, S. A., Searle, M. P., Waters, D. J., \& Hodges, K. V. (1999). Metamorphism, melting, and extension: Age constraints from the High Himalayan Slab of southeast Zanskar and northwest Lahaul. Journal of Geology, 107(4), 473-495. https:// doi.org/10.1086/314360

Webb, A. A. G. (2013). Preliminary balanced palinspastic reconstruction of Cenozoic deformation across the Himachal Himalaya (northwestern India). Geosphere, 9, 572-587. https://doi.org/10.1130/GES00787.1 
Webb, A. A. G., Yin, A., Harrison, T. M., Célérier, J., \& Burgess, W. P. (2007). The leading edge of the Greater Himalayan Crystalline complex revealed in the NW Indian Himalaya: Implications for the evolution of the Himalayan orogen. Geology, 35(10), 955-958. https://doi.org/10.1130/G23931A.1

Webb, A. A. G., Yin, A., Harrison, T. M., Celerier, J., Gehrels, G. E., Manning, C. E., \& Grove, M. (2011). Cenozoic tectonic history of the Himachal Himalaya (northwestern India) and its constraints on the formation mechanism of the Himalayan orogen. Geosphere, 7(4), 1013-1061. https://doi.org/10.1130/GES00627.1

Wiesmayr, G., \& Grasemann, B. (2002). Eohimalayan fold and thrust belt: Implications for the geodynamic evolution of the NW-Himalaya (India). Tectonics, 21(6), 1058. https://doi.org/10.1029/2002TC001363

Wyss, M., Hermann, J., \& Steck, A. (1999). Structural and metamorphic evolution of the northern Himachal Himalaya, NW India-(Spitieastern Lahul-Parvati valley traverse). Eclogae Geologicae Helvetiae, 92, 3-44.

Yin, A. (2006). Cenozoic tectonic evolution of the Himalayan orogen as constrained by along-strike variation of structural geometry, exhumation history, and foreland sedimentation. Earth-Science Reviews, 76(1-2), 1-131. https://doi.org/10.1016/j.earscirev.2005.05.004

Zhu, X. K., \& O'Nions, R. K. (1999). Monazite chemical composition: Some implications for monazite geochronology. Contributions to Mineralogy and Petrology, 137(4), 351-363. https://doi.org/10.1007/s004100050555 